\title{
※USGS
}

science for a changing world

Prepared in cooperation with the U.S. Army Corps of Engineers, Portland District

\section{Preliminary Assessment of Vertical Stability and Gravel Transport along the Umpqua River, Southwestern Oregon}

By Jim E. O'Connor, J. Rose Wallick, Steven Sobieszczyk, Charles Cannon, and Scott W. Anderson

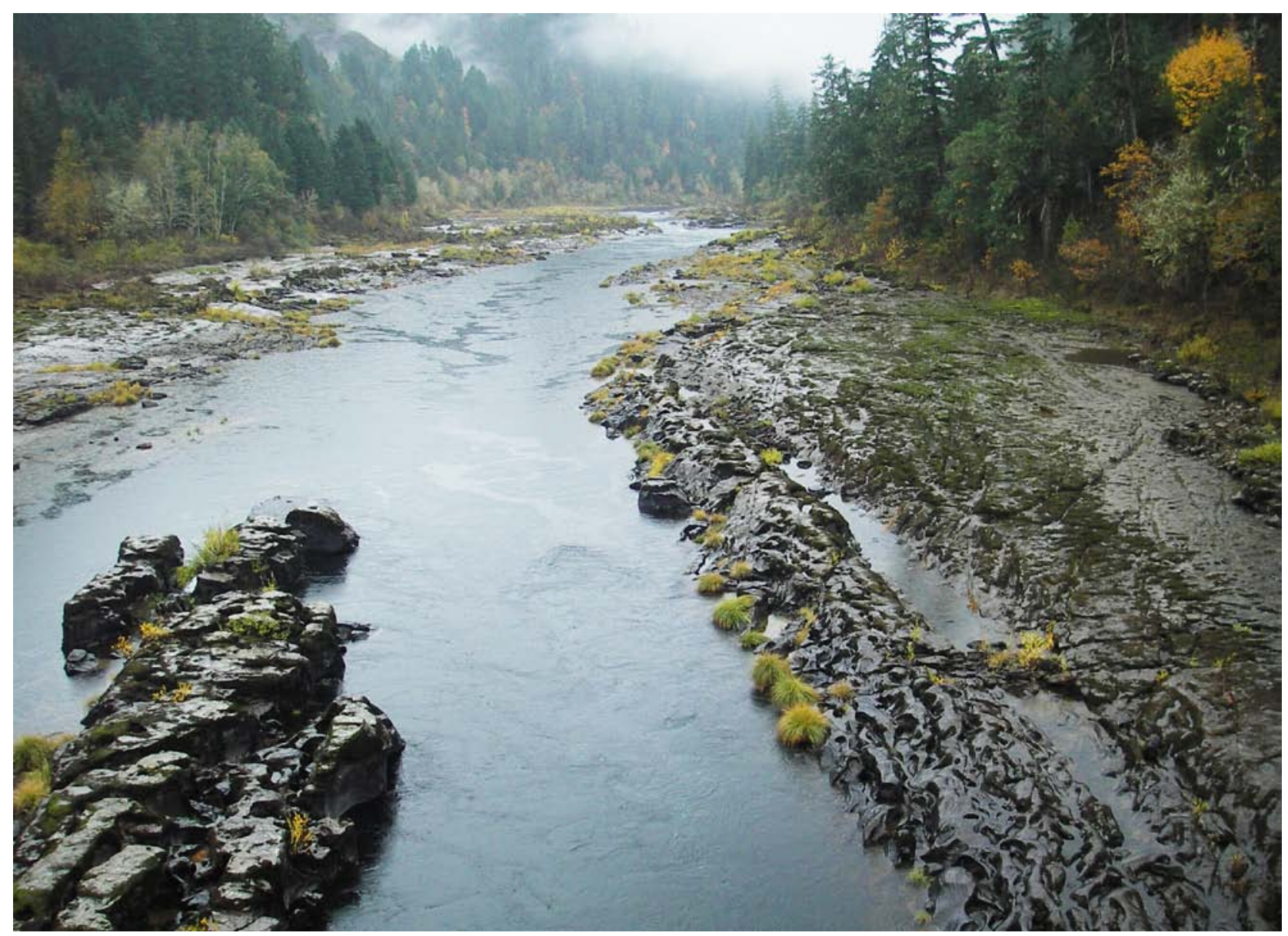

Open-File Report 2009-1010

U.S. Department of the Interior

U.S. Geological Survey 
Cover: Umpqua River at river mile 90.7, looking upstream, November 3, 2008 (Photograph by Jim O'Connor, U.S. Geological Survey) 


\section{Preliminary Assessment of Vertical Stability and Gravel Transport along the Umpqua River, Southwestern Oregon}

By Jim E. O'Connor, J. Rose Wallick, Steven Sobieszczyk, Charles Cannon, and Scott W. Anderson

Prepared in cooperation with the U.S. Army Corps of Engineers, Portland District

Open-File Report 2009-1010

U.S. Department of the Interior

U.S. Geological Survey 


\title{
U.S. Department of the Interior \\ KEN SALAZAR, Secretary
}

\author{
U.S. Geological Survey \\ Suzette M. Kimball, Acting Director
}

U.S. Geological Survey, Reston, Virginia: 2009

For more information on the USGS-the Federal source for science about the Earth, its natural and living resources, natural hazards, and the environment, visit http://www.usgs.gov or call 1-888-ASK-USGS.

For an overview of USGS information products, including maps, imagery, and publications, visit $h$ ttp://www.usgs.gov/pubprod

To order this and other USGS information products, visit http://store.usgs.gov

\footnotetext{
Suggested citation:

O'Connor, J.E., Wallick, J.R., Sobieszczyk, Steven, Cannon, Charles, and Anderson, S.W., 2009, Preliminary assessment of vertical stability and gravel transport along the Umpqua River, Oregon: U.S. Geological Survey Open-File Report 2009-1010, 40 p.
}

Use of trade, product, or firm names is for descriptive purposes only and does not imply endorsement by the U.S. Government.

Although this report is in the public domain, permission must be secured from the individual copyright owners to reproduce any copyrighted material contained within this report. 


\section{Contents}

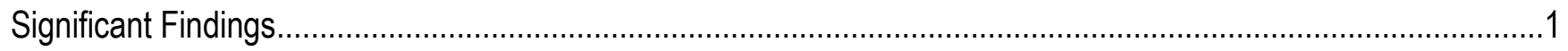

Introduction

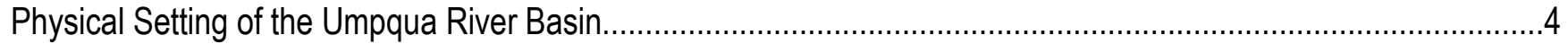

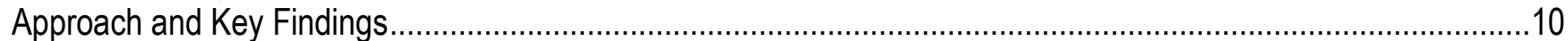

Compile and Review Historical Documents and Photographs ....................................................................10

Compilation of Historical Maps and Survey Data ......................................................................................

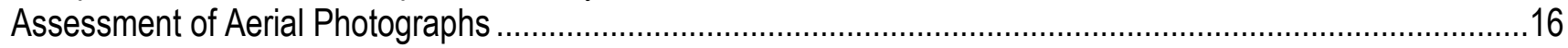

Review of Water- and Sediment-Related Studies in the Umpqua River Basin..............................................19

Review of Gravel-Operator Surveys................................................................................................20

Compile and Review Oregon Department of Transportation Umpqua River Bridge Inspection Reports ..............23

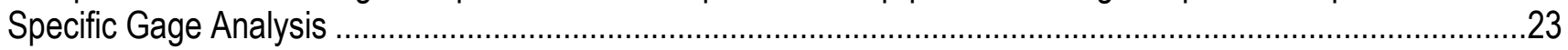

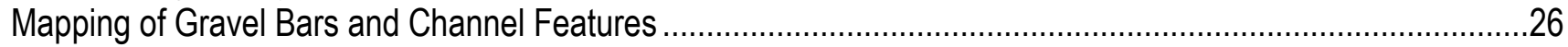

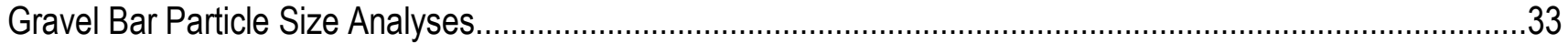

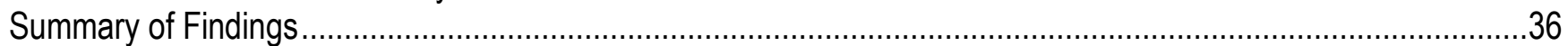

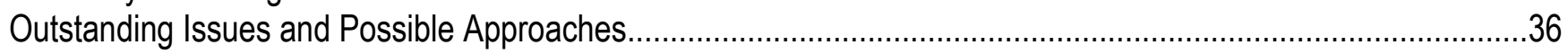

Bed-Material Budget ………......................................................................................................36

Legacy and Ongoing Effects of Placer Mining, Forest Practices, Impoundments and Instream Gravel Mining ...37

Connections between Upstream Umpqua River and Tributaries and the Tidal Reach......................................37

Balance between Sediment Supply and Transport Capacity.......................................................................38

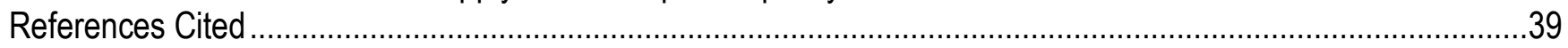

\section{Figures}

Figure 1. Maps showing (A) location of designated valley reaches and (B) geomorphic subdivisions (Ramp, 1972) for the Umpqua River basin and Douglas County, southwestern Oregon. ............................... Figure 2. Longitudinal profile, cumulative drainage area, valley reach boundaries, and locations of streamflow-gaging stations for the Umpqua River, southwestern Oregon ................................................... 4

Figure 3. Annual peak flows for selected USGS streamflow-gaging stations in the Umpqua River basin, southwestern Oregon.

Figure 4. Circa 1890s photograph of South Umpqua River upstream of Mount Nebo near Roseburg, Oregon. Courtesy Douglas County Museum (Photograph N5549a) .

Figure 5. Hydraulic mining in the Olalla District, Lookingglass Creek drainage, Oregon. Courtesy of Douglas County Museum (Photograph N5155), undated.

Figure 6. Summary of gravel bar volume changes, 2000-2008, at instream gravel mining sites along the South Umpqua River, southwestern Oregon

Figure 7. Excavation volumes for 1949-2002, for the Umpqua River Navigation (and successor companies) mining site along lower Umpqua River below RM 27, southwestern Oregon. 23

Figure 8. Sequence of stage-discharge rating curve elevations for specific discharges for long-term mainstem streamflow gages in Umpqua River, Oregon, study area.

Figure 9. Distribution and size of fluvial sediment accumulations in the Umpqua River, southwestern Oregon, study area as mapped from 2005 National Agriculture Imagery... 
Figure 10. Mapped bar areas for selected reaches of the Umpqua River basin, southwestern Oregon, from aerial photographs dated 1939, 1967, and 2005

Figure 11. Mapped channel and bar features for the Umpqua River at Tyee site, southwestern Oregon, 1939-2005.

Figure 12. Mapped channel and bar features for the Umpqua River at Cleveland Rapids site (RM 107.5-

110.5), southwestern Oregon, 1939-2005.

Figure 13. Mapped channel and bar features at the South Umpqua River site (RM 128-132),

southwestern Oregon, 1939-2005.

Figure 14. Mapped channel and bar features at the North Umpqua River site (RM 9-12.5), southwestern

Oregon, 1939-2005.

Figure 15. Mapped channel and bar features at the Lower Umpqua River site (RM 8-13), southwestern Oregon, 1939-2005.

Figure 16. Particle-size distribution for gravel bars In the North Umpqua River basin, southwestern Oregon, sampled during a November 2008 field reconnaissance.

\section{Tables}

Table 1. Summary of geomorphic and channel characteristics for valley reaches in the Umpqua River basin, southwestern Oregon.

Table 2. List of maps reviewed for this study of the Umpqua River basin, southwestern Oregon

Table 3. List of aerial photographs reviewed for this study of the Umpqua River basin, southwestern 


\section{Conversion Factors}

Inch/Pound to SI

\begin{tabular}{lll}
\hline \multicolumn{1}{c}{ Multiply } & \multicolumn{1}{c}{ By } & \multicolumn{1}{c}{ To obtain } \\
\hline cubic foot per second $\left(\mathrm{ft}^{3} / \mathrm{s}\right)$ & 0.02832 & cubic meter per second $\left(\mathrm{m}^{3} / \mathrm{s}\right)$ \\
cubic yard $\left(\mathrm{yd}^{3}\right)$ & 0.7646 & cubic meter $\left(\mathrm{m}^{3}\right)$ \\
foot $(\mathrm{ft})$ & 0.3048 & meter $(\mathrm{m})$ \\
meter $(\mathrm{m})$ & 3.281 & foot $(\mathrm{ft})$ \\
mile $(\mathrm{mi})$ & 1.609 & kilometer $(\mathrm{km})$ \\
square mile $\left(\mathrm{mi}^{2}\right)$ & 259.0 & hectare $(\mathrm{ha})$ \\
square mile $\left(\mathrm{mi}^{2}\right)$ & 2.590 & square $\mathrm{kilometer}\left(\mathrm{km}^{2}\right)$ \\
ton per year $(\mathrm{ton} / \mathrm{yr})$ & 0.9072 & metric ton per year \\
ton, short $(2,000 \mathrm{lb})$ & 0.9072 & megagram $(\mathrm{Mg})$ \\
\hline
\end{tabular}

Vertical coordinate information is referenced to the National Geodetic Vertical Datum of 1929 (NGVD 29). Horizontal coordinate information is referenced to the North American Datum of 1983 (NAD 83).

Elevation, as used in this report, refers to distance above the vertical datum. 
This page is intentionally blank. 


\title{
Preliminary Assessment of Vertical Stability and Gravel Transport along the Umpqua River, Oregon
}

\author{
By Jim E. O'Connor, J.Rose Wallick, Steven Sobieszczyk, Charles Cannon, and Scott W. Anderson
}

\section{Significant Findings}

This preliminary study of (1) gravel transport in the Umpqua River basin, (2) possible historical changes to physical channel and floodplain conditions, and (3) potential future studies reveals that:

- The alluvial reaches of the Umpqua River system can be divided into six valley reaches based on geomorphology, hydrology, and land-use history. The mainstem Umpqua River can be divided into the Tidal, Coast Range, and Garden Valley Reaches; the South Umpqua River can be divided into the Roseburg and Days Creek Reaches; and the alluvial portion of the North Umpqua River is a single reach consisting of the lowermost 29 river miles upstream of the South Umpqua confluence. These reaches and their contributing areas differ in their capacity to produce, store, and transport bed-material sediment.

- Historical accounts and information dating to the 1820s demonstrate that the Umpqua River, aside from the Tidal Reach, flowed on bedrock for much of its length. Sand and gravel accumulations were notably sparse. These two observations indicate that the channel is incising over geological timescales and that sediment transport is limited by supply.

- The primary human activities that have likely had effects on bed material transport and the extent and volume of gravel bars are (1) intense placer mining (including hydraulic quarrying of alluvium) beginning in the 1850s, especially for tributaries of the South Umpqua River; (2) dam building on the North Umpqua River and in the Cow Creek drainage (tributary to the South Umpqua River); (3) road building and forest practices in upland areas; (4) inchannel dredging in the Tidal Reach; and (5) gravel mining from active gravel bars, primarily in the Tidal, Garden Valley, Roseburg, and Days Creek Reaches. These influences have likely had spatially and temporally varying effects on gravel transport rates and the size and volume of gravel bars. For some reaches, disentangling these various factors will be challenging.

- Several sources of historical maps, surveys, and aerial photographs could support quantitative analysis of plan-view changes and riparian conditions dating back to the General Land Office surveys of the 1850s. Some information is available, including channel navigation and flood studies, which could be used to evaluate changes in channel bathymetry.

- Previous sediment studies conducted for water years 1956-73 indicate that at their confluence, the South Umpqua River contributes more than twice the sediment as the North Umpqua River, with Cow Creek being the major contributor to the South Umpqua River.

- Repeat gravel bar and channel surveys provided by gravel mining companies and other sources indicate that extracted volumes are not rapidly replenished in the Tidal Reach, with possible incision indicated by the latest 2002 surveys, and that bars in the Roseburg and Days Creek Reaches (on the 
South Umpqua River) have been rebuilding since last mining in 2004, especially after high flows in 2005-06.

- Reviews of approximately 35 bridge inspection reports indicate that nearly all bridge piers are set in bedrock. Some footings show scour that is mostly attributable to bedrock erosion.

- Specific gage analyses for gages on the mainstem Umpqua River (near Eldon), South Umpqua River near Brockway, and the North Umpqua River at Winchester show little or no incision over their periods of record.

- Systematic mapping of observable gravel bars for all reaches from 2005 aerial photographs shows that the Tidal Reach has by far the greatest area of fluvial sediment surfaces, but many of these are mud and sand flats. Elsewhere, the Roseburg Reach (South Umpqua River) stands out as having the most abundant gravel bars, indicating much greater bed-material production rates for the South Umpqua River and in particular the importance of Cow Creek in contributing bed sediment.

- Analyses of aerial photograph sequences for five short reaches for 1939, 1967, and 2005 show no clear trends, but extending this analysis for more reaches and more time periods would be necessary to determine if trends in gravel bar area, riparian conditions, and channel morphology exist.

\section{Introduction}

This report addresses physical channel issues related to instream gravel mining on the Umpqua River and its two primary tributaries, the North and South Umpqua Rivers. This analysis constitutes a "Phase I" investigation, as designated by an interagency team cochaired by the U.S. Army Corps of Engineers, Portland District, and the Oregon Department of State Lands to address instream gravel mining issues across Oregon. Phase I analyses rely primarily on existing datasets and cursory analysis to determine the vertical stability of a channel to ascertain whether a particular river channel is aggrading, degrading, or at equilibrium. Additionally, a Phase I analysis identifies other critical issues or questions pertinent to physical channel conditions that may be related to instream gravel mining activities.

This analysis can support agency permitting decisions as well as possibly indicating the need for additional studies. This specific analysis focuses on the mainstem Umpqua River from the Pacific Ocean at River Mile (RM) 0 to the confluence of the North and South Umpqua Rivers (at RM 111.8), as well as the lower $29 \mathrm{mi}$ of the North Umpqua River and the lower $80 \mathrm{mi}$ of the South Umpqua River (fig. 1). It is within these reaches where mining of gravel bars for aggregate has been most prevalent. 


\section{A}

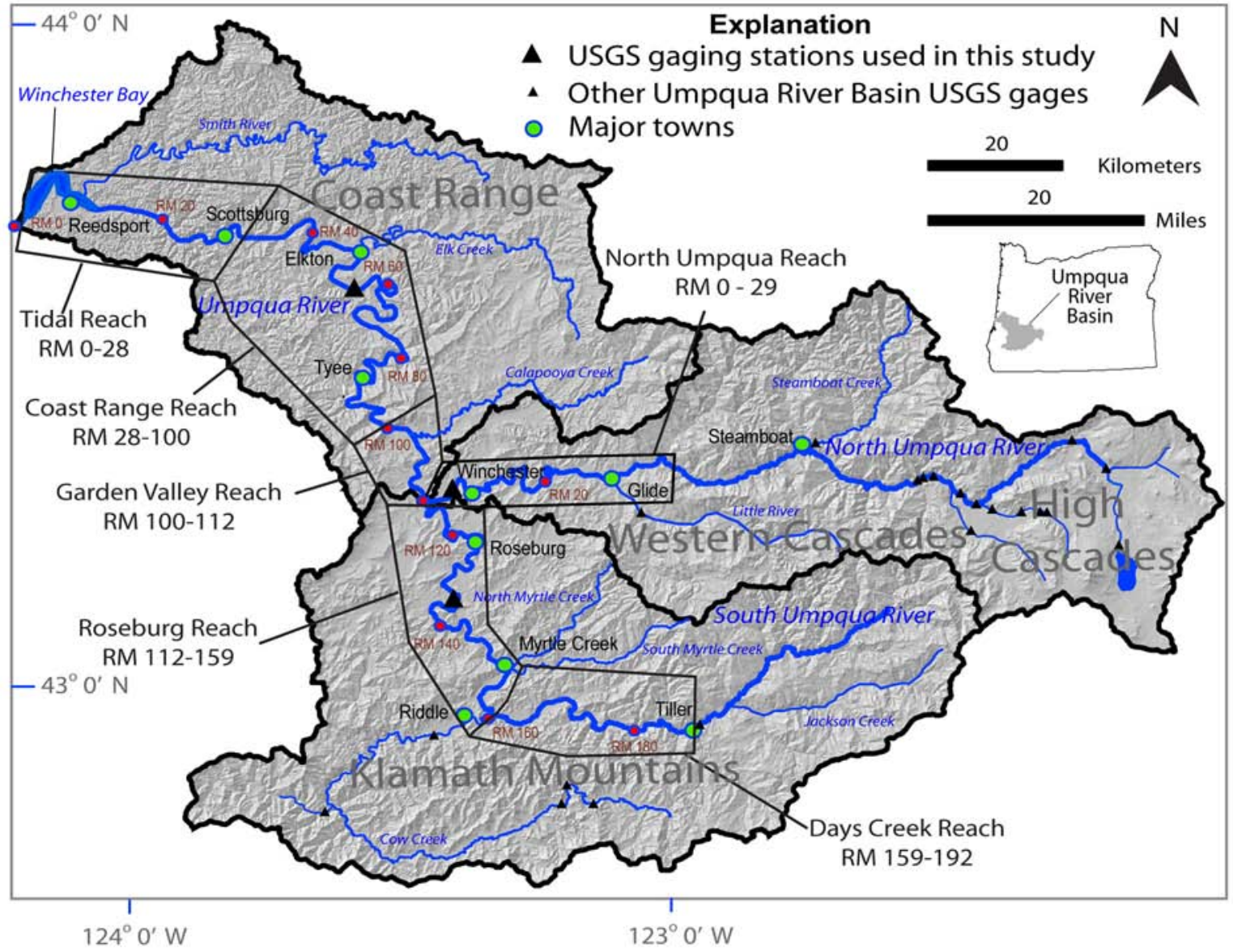

B

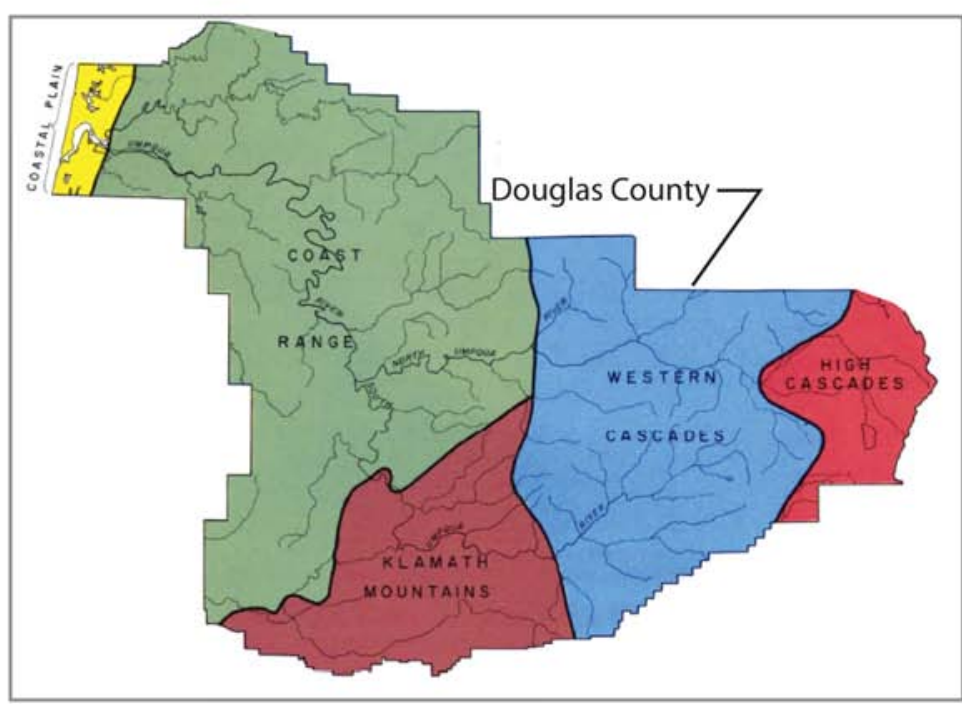

Figure 1. (A) location of designated valley reaches and (B) geomorphic subdivisions (Ramp, 1972) for the Umpqua River basin and Douglas County, southwestern Oregon. 


\section{Physical Setting of the Umpqua River Basin}

The Umpqua River drains 4,673 $\mathrm{mi}^{2}$ of western Oregon before draining into the Pacific Ocean at Winchester Bay near the town of Reedsport (fig. 1). The drainage basin is flanked to the north by the Siuslaw and Willamette River basins, to the east by the Deschutes and Klamath River drainages, and to the south by the Rogue and Coquille River basins. The basin has its headwaters in the Cascade Range is bounded on the south by the Klamath Mountains, and transects the Coast Range before entering the Pacific Ocean. The North and South Umpqua Rivers join in the generally lower terrain between the Cascade Range and the Coast Range, with the North Umpqua River draining parts of the High Cascades and Western Cascade physiographic provinces, and the South Umpqua River draining parts of the Western Cascades and Klamath Mountain provinces. The lower parts of both forks, as well as the mainstem Umpqua River, are wholly within the Coast Range physiographic province (fig. 1B, Ramp, 1972).

After exiting the Western Cascades physiographic province, the North and South Umpqua Rivers flow generally westward before joining $6 \mathrm{mi}$ northwest of Roseburg. For another $12 \mathrm{mi}$, the mainstem Umpqua River meanders northwestward though two large valleys before bisecting the higher portion of the Coast Range within a narrow valley trending northwest and then west for 90 mi before exiting into the coastal plain for the last $10 \mathrm{mi}$ before entering the Pacific Ocean. The main tributaries of the mainstem Umpqua River are the Smith River (371 mi ${ }^{2}$ ), Elk Creek (292 $\mathrm{mi}^{2}$ ), and the Calapooya River $\left(246 \mathrm{mi}^{2}\right.$ ). The Umpqua River begins at the confluence of North Umpqua and South Umpqua Rivers at RM 111.8, where the North Umpqua River drains 1,359 $\mathrm{mi}^{2}$, with all major inflow entering upstream of the study area at Little River $\left(206 \mathrm{mi}^{2}\right)$ and Steamboat Creek (164 $\left.\mathrm{mi}^{2}\right)$. At the confluence, the South Umpqua River has a drainage area of $1,801 \mathrm{mi}^{2}$, with the main tributaries in the study area being Lookingglass Creek (161 mi ${ }^{2}$ ), Myrtle Creek (119 mi ${ }^{2}$ ), Cow Creek (499 $\left.\mathrm{mi}^{2}\right)$, and Jackson Creek $\left(189 \mathrm{mi}^{2}\right)$ (figs. 1 and 2).

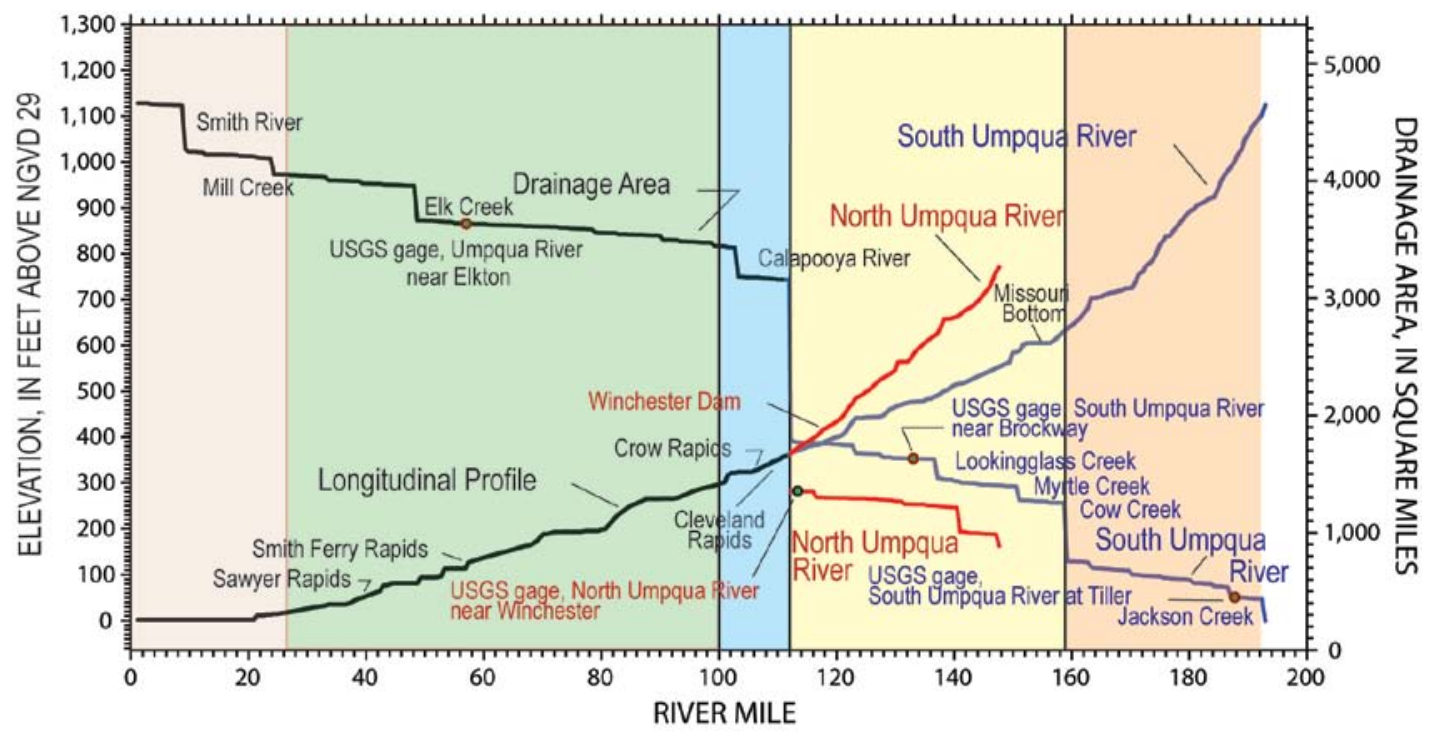

Figure 2. Longitudinal profile, cumulative drainage area, valley reach boundaries, and locations of streamflow-gaging stations for the Umpqua River, southwestern Oregon. Drainage area calculated from USGS 10-meter digital elevation data. 
The study area encompasses the downstream alluvial sections of the North and South Umpqua Rivers and the entire mainstem Umpqua River. For both forks, the alluvial sections begin where the rivers exit the mountainous headwaters, widen, and flow on a mixed bed of bedrock and alluvium flanked by variable widths of floodplain and terraces. For the North Umpqua River, this transition to a dominantly alluvial character approximately corresponds with the confluence of the Little River at RM 29.1 (river miles for the North Umpqua River are measured with respect to the confluence with the South Umpqua River.) Downstream of the Little River confluence, the North Umpqua River is generally 200 to $300 \mathrm{ft}$ wide and flows on a bed of sandstone and basalt, locally mantled by thin accumulations of sand and gravel. The average gradient from the Little River confluence to the confluence with the South Umpqua River is 0.0018 (table 1). In this reach, the North Umpqua River is flanked by a valley bottom typically less than $0.5 \mathrm{mi}$ wide formed of recent floodplain deposits and small terrace remnants. 
Table 1. Summary of geomorphic and channel characteristics for valley reaches in the Umpqua River basin, southwestern Oregon

\begin{tabular}{|c|c|c|c|c|c|c|}
\hline \multirow[b]{2}{*}{ Attribute } & \multicolumn{6}{|c|}{ Valley Reach } \\
\hline & Tidal & Coast Range & Garden Valley & Roseburg & Days Creek & North Umpqua \\
\hline Position & RM 0-27.5 & RM 27.5-100 & RM 100-111.8 & RM 111.8-158.9 & RM 158.9-192.4 & RM 0-29.0 \\
\hline Reach definition & Tidally affected & $\begin{array}{l}\text { Confined valley, } \\
\text { bedrock channel }\end{array}$ & $\begin{array}{l}\text { Unconfined below } \\
\text { North and South } \\
\text { Umpqua River } \\
\text { confluence }\end{array}$ & $\begin{array}{l}\text { Cow Creek } \\
\text { confluence to North } \\
\text { Umpqua River } \\
\text { confluence }\end{array}$ & $\begin{array}{l}\text { Jackson Creek } \\
\text { confluence to Cow } \\
\text { Creek confluence }\end{array}$ & $\begin{array}{l}\text { Little River } \\
\text { confluence to South } \\
\text { Umpqua River } \\
\text { confluence }\end{array}$ \\
\hline General valley setting & $\begin{array}{l}\text { Estuary, confined } \\
\text { valley opening to } \\
\text { bay within coastal } \\
\text { plain }\end{array}$ & $\begin{array}{l}\text { Confined valley } \\
\text { with local valley } \\
\text { widenings }\end{array}$ & Unconfined & $\begin{array}{l}\text { Alternating confined } \\
\text { and unconfined }\end{array}$ & $\begin{array}{l}\text { Alternating } \\
\text { confined and } \\
\text { unconfined }\end{array}$ & $\begin{array}{l}\text { Alternating confined } \\
\text { and unconfined }\end{array}$ \\
\hline General channel character & $\begin{array}{l}\text { Low gradient, } \\
\text { sand and gravel } \\
\text { bed }\end{array}$ & $\begin{array}{l}\text { Steep, bedrock } \\
\text { rapids separated } \\
\text { by flats }\end{array}$ & $\begin{array}{l}\text { Alternating } \\
\text { bedrock and gravel }\end{array}$ & $\begin{array}{l}\text { Alternating bedrock } \\
\text { and gravel }\end{array}$ & & $\begin{array}{l}\text { Mostly bedrock, pool } \\
\text { and drop }\end{array}$ \\
\hline $\begin{array}{l}\text { Area at downstream end of } \\
\text { segment (square miles) }\end{array}$ & $4,672.7$ & $4,051.1$ & $3,438.0$ & $1,801.6$ & 757.4 & $1,359.8$ \\
\hline $\begin{array}{l}\text { Area at upstream end of } \\
\text { segment in (square miles) }\end{array}$ & $4,051.1$ & $3,438.0$ & $3,161.5$ & $1,256.4$ & 435.3 & $1,216.8$ \\
\hline Average gradient & 0.00012 & 0.00073 & 0.00098 & 0.00100 & 0.00249 & 0.00177 \\
\hline Number of bars & 5 & 17 & 5 & 72 & 33 & 24 \\
\hline Gravel bars per river mile & 0.07 & 0.09 & 0.15 & 0.55 & 0.35 & 0.28 \\
\hline Total area of gravel bars (acres) & $22,782.6$ & 91.9 & 18.7 & 261.6 & 123.2 & 38.9 \\
\hline Average gravel bar area (acres) & $4,556.52$ & 5.41 & 3.75 & 3.63 & 3.73 & 1.62 \\
\hline $\begin{array}{l}\text { Gravel area per mile of river } \\
\text { (acres/mile) }\end{array}$ & 848.53 & 1.35 & 1.53 & 5.45 & 3.60 & 1.25 \\
\hline Major flow factors & Tidally affected & $\begin{array}{l}\text { Minimal } \\
\text { regulation }\end{array}$ & Minimal regulation & $\begin{array}{l}\text { Galesville } \\
\text { Reservoir, closed } \\
\text { October 7, 1985, } \\
\text { regulates } 74.3 \\
\text { square miles of Cow } \\
\text { Creek basin (5.9\% } \\
\text { of contributing area } \\
\text { at upper end of } \\
\text { segment) }\end{array}$ & None & $\begin{array}{l}\text { Pacific Power dams } \\
\text { constructed } 1952- \\
1955 \text { regulate } \\
\text { (slightly) } 430 \text { square } \\
\text { miles ( } 35 \% \text { of the } \\
\text { area at the upper end } \\
\text { of segment) }\end{array}$ \\
\hline
\end{tabular}


Table 1. Summary of geomorphic and channel characteristics for valley reaches in the Umpqua River basin, southwestern Oregon—continued

\begin{tabular}{|c|c|c|c|c|c|c|}
\hline \multirow[b]{2}{*}{ Attribute } & \multicolumn{6}{|c|}{ Valley Reach } \\
\hline & Tidal & Coast Range & Garden Valley & Roseburg & Days Creek & North Umpqua \\
\hline Major sedimentation factors & $\begin{array}{l}\text { Change in } \\
\text { gradient promotes } \\
\text { deposition of } \\
\text { bedload and } \\
\text { suspended load, } \\
\text { Smith River } \\
\text { sediment inputs, } \\
\text { (100,000-500,000 } \\
\text { cubic yards per } \\
\text { year), sand and } \\
\text { gravel removal. }\end{array}$ & $\begin{array}{l}\text { Tributary } \\
\text { sediment inputs, } \\
\text { local landuse and } \\
\text { forest practices }\end{array}$ & $\begin{array}{l}\text { Local sand and } \\
\text { gravel mining, } \\
\text { forest practices, } \\
\text { Calapooya River } \\
\text { sediment input }\end{array}$ & $\begin{array}{l}\text { Late 19th century } \\
\text { placer mining (Cow } \\
\text { Creek, Myrtle } \\
\text { Creek, Canyon } \\
\text { Creek, and South } \\
\text { Umpqua River), } \\
\text { forest practices, } \\
\text { sand and gravel } \\
\text { mining, tributary } \\
\text { sediment inputs }\end{array}$ & $\begin{array}{l}\text { Forest practices, } \\
\text { sand and Gravel } \\
\text { mining, tributary } \\
\text { sediment inputs }\end{array}$ & $\begin{array}{l}\text { Pacific Power dams } \\
\text { trap upstream } \\
\text { sediment, land-use }\end{array}$ \\
\hline Channel disturbance factors & $\begin{array}{l}\text { Historic } \\
\text { navigation } \\
\text { dredging, sand } \\
\text { and gravel } \\
\text { mining, rock } \\
\text { removal for } \\
\text { navigation } \\
\text { improvement near } \\
\text { Scottsburg, road } \\
\text { corridor }\end{array}$ & $\begin{array}{l}\text { Late 19th } \\
\text { century } \\
\text { navigation } \\
\text { improvements, } \\
\text { temporary mill } \\
\text { dam at Kellogg } \\
\text { (removed 1871), } \\
\text { road corridor }\end{array}$ & $\begin{array}{l}\text { Late 19th century } \\
\text { navigation } \\
\text { improvements, } \\
\text { sand and gravel } \\
\text { mining }\end{array}$ & $\begin{array}{l}\text { Local navigation } \\
\text { improvements, } \\
\text { transportation } \\
\text { infrastructure, log } \\
\text { driving, sand and } \\
\text { gravel mining, } \\
\text { placer mining, 19th } \\
\text { century mill dams }\end{array}$ & $\begin{array}{l}\text { Transportation } \\
\text { infrastructure, sand } \\
\text { and gravel mining, } \\
\text { log driving(?), } \\
\text { placer mining }\end{array}$ & $\begin{array}{l}\text { Navigation } \\
\text { improvement, log } \\
\text { driving, Winchester } \\
\text { Dam at RM } 7\end{array}$ \\
\hline General channel trends & $\begin{array}{l}\text { Some evidence of } \\
\text { local incision } \\
\text { historically near } \\
\text { gravel mining } \\
\text { operations } \\
\text { (CH2M-Hill, } \\
\text { 1971; Janine M. } \\
\text { Castro, written } \\
\text { commun., 2008) }\end{array}$ & $\begin{array}{l}\text { Channel } \\
\text { historically and } \\
\text { presently on } \\
\text { bedrock. Little or } \\
\text { no evident } \\
\text { change (photos, } \\
\text { specific gage } \\
\text { analysis for } \\
\text { Elkton gage). }\end{array}$ & $\begin{array}{l}\text { Channel } \\
\text { historically and } \\
\text { presently on } \\
\text { bedrock. No } \\
\text { obvious change } \\
\text { evident from } \\
\text { inspection of aerial } \\
\text { and oblique } \\
\text { photographs, } \\
\text { analysis of bar } \\
\text { area. }\end{array}$ & $\begin{array}{l}\text { Channel historically } \\
\text { and presently on } \\
\text { bedrock. No obvious } \\
\text { change evident from } \\
\text { inspection of aerial } \\
\text { and oblique } \\
\text { photographs, } \\
\text { analysis of bar area, } \\
\text { and specific gage } \\
\text { analysis. }\end{array}$ & $\begin{array}{l}\text { Channel locally on } \\
\text { bedrock. No } \\
\text { evident trends, } \\
\text { although limited } \\
\text { data for this reach. }\end{array}$ & $\begin{array}{l}\text { Channel historically } \\
\text { and presently on } \\
\text { bedrock. No evident } \\
\text { change from specific } \\
\text { gage analysis. }\end{array}$ \\
\hline
\end{tabular}


For the South Umpqua River, the confluence of Jackson Creek at RM 192.5 (measured with respect to the Pacific Ocean) near Tiller approximately marks the transition from a confined mountain channel to a mixed alluvial and bedrock channel locally flanked by active gravel bars, floodplain surfaces, and terraces. For the 33.5 mi between the Jackson Creek and Cow Creek junctions, the South Umpqua River flows generally westward with an average gradient of 0.0025 (table 1) and a width typically less than $150 \mathrm{ft}$. In this reach, the valley alternates between confined canyon reaches and sections as wide as $1 \mathrm{mi}$. Wider sections contain channel-flanking gravel bars, floodplains, tributary fans, and terrace deposits.

With the confluence of Cow Creek at RM 158.9, the drainage area of the South Umpqua River increases by about one-third and the channel widens to between 200 and $400 \mathrm{ft}$. For the $47.1 \mathrm{mi}$ reach between the Cow Creek confluence to the junction with the North Umpqua River, the South Umpqua River flows generally northward on an alternating bed of bedrock and alluvium with a average gradient of 0.001 (table 1), winding through canyons alternating with valleys as wide as $2 \mathrm{mi}$, and is locally flanked by gravel bars, floodplains, and terraces.

The general character of the South Umpqua River continues another 12 mi downstream of the confluence with the North Umpqua River, where the Umpqua River enters a confined section at RM 100. From here to about RM 25, the river flows within deep and narrow meanders incised through the Coast Range, with narrow flanking floodplains and terraces almost everywhere less than 0.5 mi wide. The channel in this reach is typically 300 to $600 \mathrm{ft}$ wide and consists of long pools separated by bedrock rapids; the average gradient between RM 100 and the head of tide at RM 27.5 is 0.0073 (table 1). From RM 25 to the mouth, the Umpqua River is tidally affected, progressively widens, and is flanked by low floodplains, tidal marshes and sand and gravel bars, especially downstream of the mouth of the Smith River at RM 11.

Information on basin hydrology derives from U.S. Geological Survey (USGS) streamflowmeasurement records in the basin extending discontinuously back to 1905. Much of these data are available at http://waterdata.usgs.gov/or/nwis/nwis, with some synthesis provided by Jones and Stearns (1930). The mean annual flow of the Umpqua River near Elkton, at RM 56.9 is 7,365 $\mathrm{ft}^{3} / \mathrm{s}$, which closely corresponds to the combined mean flows for the North Umpqua River at Winchester (RM 1.8; 3,698 $\mathrm{ft}^{3} / \mathrm{s}$ ), and the South Umpqua River near Brockway (RM 132.8, 2,755 $\mathrm{ft}^{3} / \mathrm{s}$ ). Despite a contributing area 25 percent smaller than the South Umpqua River, the North Umpqua River supplies more than 50 percent of the water at Elkton (compared to 37 percent provided by the South Umpqua River), chiefly owing to a greater area of high elevation terrain subject to orographically enhanced precipitation. This high terrain, associated with Quaternary volcanic rocks of the High Cascade physiographic province, also explains the much lower intraannual flow variability of the North Umpqua River, where the mean January flow is only 6.7 times that of August. By contrast, the mean January flow for the South Umpqua River is 57 times greater than the mean August flow. The young volcanic uplands of the North Umpqua River headwaters have poorly integrated surface drainage networks and host large-volume ground-water systems, attenuating surface runoff and feeding large spring complexes that maintain high dry season flows in comparison with more rapid runoff derived from the more dissected and older rocks of the Western Cascades and Klamath Mountain terrains underlying much of the South Umpqua River headwaters (Jones and Stearns, 1930).

Peak flows in the Umpqua River basin typically derive from winter frontal systems, with the largest flows resulting from regional rain-on-snow events. The peak of record for both forks and the mainstem was in late December 1964, when 265,000 ft 3 /s was reported for the mainstem near Elkton, and 150,000 and 125,000 $\mathrm{ft}^{3} / \mathrm{s}$ were reported for the North Umpqua and South Umpqua Rivers, respectively. The 1964 flood probably was the largest since the rain-on-snow flood of 1861. The 2-year- 
recurrence-interval flow is about 49,000 ft 3 /s for the North and South Umpqua Rivers, and 94,500 $\mathrm{ft}^{3} / \mathrm{s}$ for the mainstem Umpqua River (Harris and others, 1979). Since the early 1950s, flow has been slightly regulated by Pacific Power hydroelectric projects on the North Umpqua River; likewise, on the South Umpqua River, construction of Galesville Reservoir in 1985 on Cow Creek may slightly affect peak and low flows, although plots of peak flows (fig. 3) show no marked effect of the dams for either river.

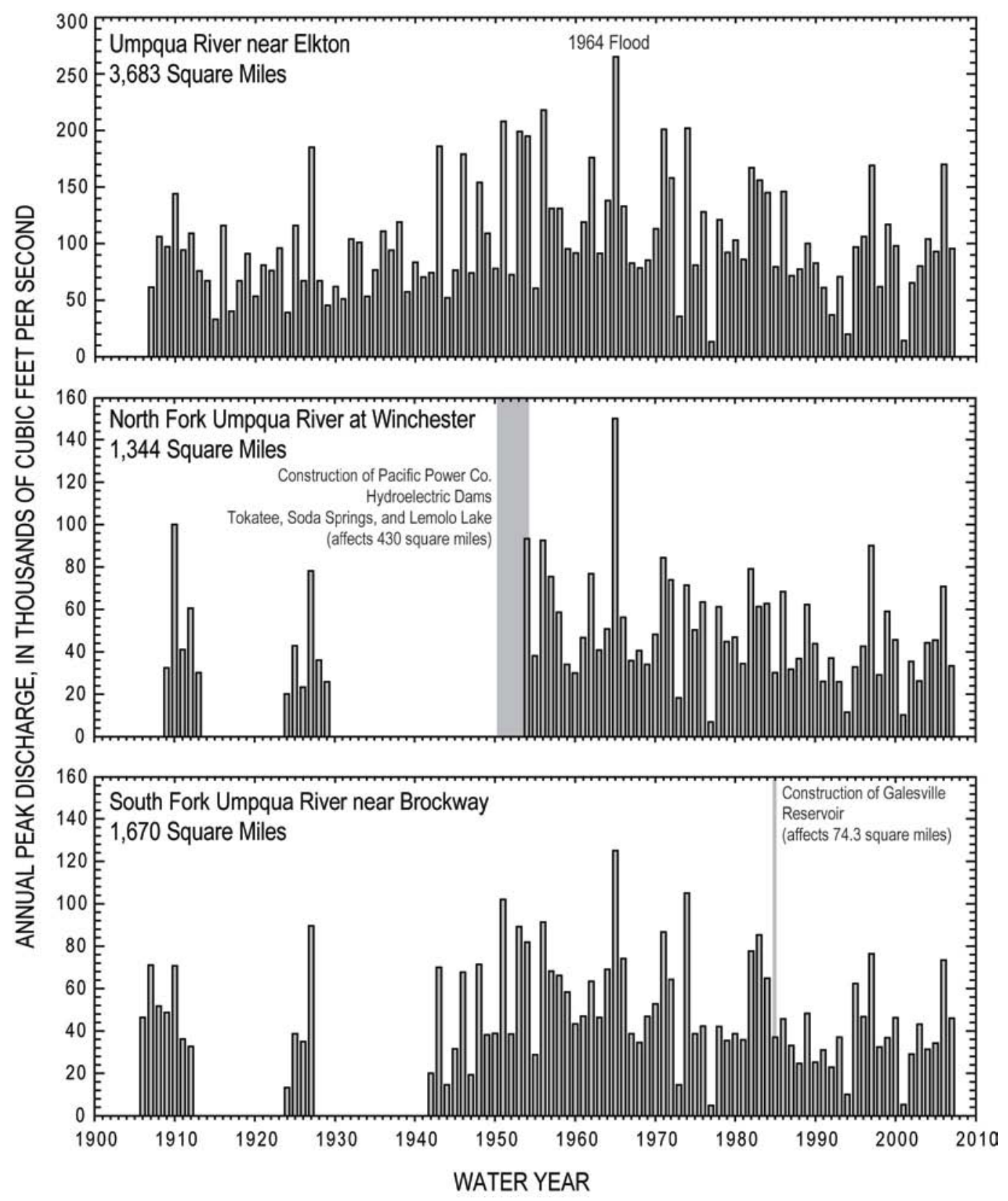

Figure 3. Annual peak flows for selected USGS streamflow-gaging stations in the Umpqua River basin, southwestern Oregon.

Sediment conditions owe to the combined effects of geology, physiography, hydrology, and land use. Little specific work has been reported for much of the Umpqua River basin, with the exception of 
the sediment budget analysis for the North Umpqua River conducted as part of the Federal Energy Regulatory Commission (FERC) relicensing of Pacific Power's North Umpqua Hydroelectric Project (Stillwater Sciences, 2000) and USGS sediment studies conducted in the 1960s and 1970s (Onions, 1969; Curtiss, 1975). The primary factors that exacerbate hydrologic responses-high drainage densities, high relief, older and erodible rocks_-likely also promote greater supplies of bed material (see, for example, O'Connor and others, 2003). Consistent with this is the finding of Curtiss (1975) that the South Umpqua River produces an annual sediment discharge more than twice that of the North Umpqua River, based on USGS suspended-load measurements at multiple sites between 1956 and 1973,. Nevertheless, the common occurrence of inchannel bedrock for both forks and the mainstem upstream of the tidal reach indicates that bed material transport is limited by the amount supplied from upstream and tributaries.

The overall physical setting, as well as the distribution of instream gravel-mining permits (Oregon Department of State Lands, written commun., 2008), lends itself to delineation of valley reaches to help organize sediment-related issues, analyses, and findings (fig. 1; table 1). These reaches are, from downstream to upstream (1) Tidal Reach, between RM 0 and approximately 28, distinguished by low gradients, expansive sediment deposits, and historic gravel sand and gravel removal for navigation and aggregate; (2) Coast Range Reach, between approximately RM 28 and 100, characterized by a confined valley with bedrock channel and few gravel deposits; (3) Garden Valley Reach of broad valleys, between where the Umpqua River enters the Coast Range at RM 100 and the North Umpqua River and South Umpqua River confluence at approximately RM 112, a reach of historic instream gravel mining; (4) Roseburg Reach of the South Umpqua River, between the confluence with the North Umpqua River (RM 112) and the Cow Creek confluence at RM 158.9, where there are abundant gravel bars and several recently active instream gravel mining operations; (5) Days Creek Reach of the South Umpqua River, between the Cow Creek confluence at approximately RM 159 and 192, which constitutes the uppermost alluvial reach of the South Umpqua River; and (6) North Umpqua River, between RM 0 and the Little River confluence at RM 29, a reach locally flanked by alluvial deposits but with no recent instream gravel mining.

\section{Approach and Key Findings}

For this study, we reviewed existing datasets, collected data, and analyzed information regarding channel processes and gravel transport for the Umpqua River. In addition, we conducted site visits in August and November 2008. These activities were focused on assessing physical river conditions and trends - in particular the locations, area, and extent of gravel bars and information pertaining to channel aggradation or incision. We also examined broader land-use and geomorphic factors pertinent to gravel transport, distribution, and links to physical habitat conditions. The scope was such that the data review and analyses were not necessarily exhaustive, but focused on gathering information to evaluate present trends and conditions, identify outstanding questions, and guide future studies. The following sections summarize each of the major activities and key findings.

\section{Compile and Review Historical Documents and Photographs}

We reviewed several Umpqua River basin historical documents (largely summarized by Beckham [1986] and Winterbothom [1994, 2000]) for observations and accounts pertinent to channel conditions. The most useful of these are reports of early exploration and navigation surveys documenting channel characteristics at first European-American settlement. Accounts of historic landuse activities possibly affecting channels also were useful. Abundant archival photographs, at the 
Douglas County Historical Society and elsewhere, locally document channel conditions as far back as circa 1900.

A primary conclusion from inspection of these historical sources is that gravel was scarce in many reaches of the Umpqua River. This is particularly evident for the Coast Range Reach of the mainstem Umpqua River. For example, David Douglas, a botanist (and county namesake) accompanying an expedition of the Hudson's Bay Company, describes his evening activities at their camp near Elkton (Douglas, 1914, p. 223; RM 48.5; Coast Range Reach):

"I employed myself chopping wood, kindling the fire, and forming the encampment; and after, in the twilight, bathed in the river: course north-west; bed sandstone; ninety yards broad; not deep, but full of holes and deep chinks worn out by the water."

Similarly John Work, employed by the Hudson’s Bay Company, describes following the mainstem Umpqua River between Elkton and Scottsburg (RM 27.5) in his journal entry for June 8, 1834 (Scott, 1923): "No stones worth mentioning all the way: the river runs on a bed of soft slatey rock." Two weeks later, on June 17, John Work was camping along the Umpqua River just downstream of the Calapooya River confluence (RM 102.5; Garden Valley Reach) where he reported:

"The Umquah here is about 150 yards wide \& runs over a rocky bottom of soft slatey rock \& is not very deep. A horse can ford it at present.”

The most extensive early survey was by U.S. Army Engineers lieutenant R.S. Williamson in 1870 to investigate navigation possibilities. His report (U.S. House of Representatives, 1871) described the several bedrock rapids between Scottsburg and Roseburg and provided a general characterization of the river:

"The average width of the river, when bankfull, appeared to be about 200 feet; but at its extreme low-water stage the water is divided at many places into half a dozen or more streams, varying in width from two to thirty feet, and separated from each other by walls of rock sometimes five or six feet in height. In passing though some of these narrow place[s] the velocity of the current was 400 feet per minute. At each of these rapids between the channel and the shore there is a bench of sandstone, generally flat, varying from two to five feet in height above the low-water mark, and averaging about seventy-five feet in width. During ordinary stages of the river this is covered with water. The river contains no sand-bars, its bottom being coarse gravel, on solid bed-rock; consequently any improvements which may be made to the river are likely to be permanent.”

A subsequent survey in 1910 encompassing most of the Roseburg, Garden Valley, and Coast Range Reaches by the Junior Engineer F.E. Leefe of the U.S. Engineer Office (U.S. House of Representatives, 1911) reiterates Williamson’s findings:

"In the stretch of river under examination between Roseburg and Scottsburg, a distance of 86 miles, the low water fall is about 465 feet. Throughout this distance the river at low water is a succession of rocky rapids with pools of quiet water between, of varying lengths and depths. The river flows over a rocky sandstone bottom much of the way, with many dangerous reefs and projections. With such a fall, averaging nearly 51/2 per mile, the current is strong over the rapids at all stages.”

Although sand and gravel accumulations are barely mentioned in many of these accounts of the South and mainstem Umpqua Rivers, except for noting their scarcity, some historical photographs show 
bars flanking the channel (fig. 4). We have found fewer early descriptions of the Days Creek Reach of the South Umpqua River at the time of first exploration, but it too was apparently locally flowing on bedrock, at least near its downstream end, because inchannel potholes near the Cow Creek confluence were targets for gold miners in the 1850s (Beckham, 1986, p. 93).

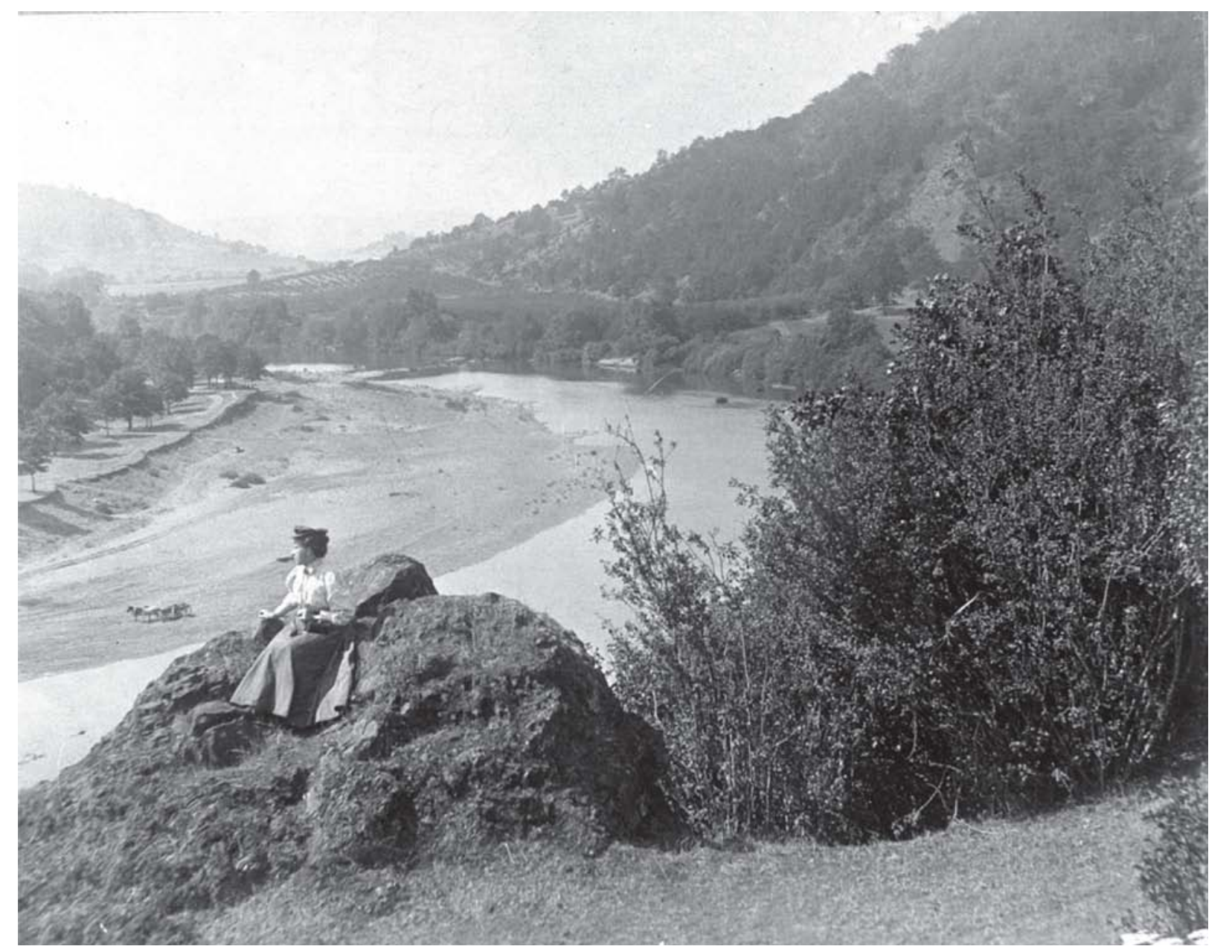

Figure 4. Circa 1890s photograph of South Umpqua River upstream of Mount Nebo near Roseburg, Oregon. Courtesy Douglas County Museum (Photograph N5549a)

Although no detailed surveys were conducted for the North Umpqua River, reports by the Wilkes Expedition on their 1841 overland trip between the Willamette Valley and San Francisco Bay (including geologist James Dwight Dana) state that the North Umpqua River ran on bedrock where they crossed it near the present location of Winchester (North Umpqua RM 7; Dana, 1849, p. 662). Similarly, Winterbotham, (2000, p. 133) noted:

"The North Umpqua River has been pronounced, by experts in the driving of streams, to be the best driving stream in Oregon or Washington. It is singularly free from shifting sand bars and gravel shoals....”

The character of the Tidal Reach was distinctly different; drifting sand and gravel bars caused persistent navigation problems between the mouth and the head of tide at Scottsburg (RM 27.5), leading 
to multiple bathymetric surveys beginning in the late 18th century (summarized by Beckham, 1986, p. 149-152). These issues ultimately resulted in construction of the jetties and substantial and ongoing dredging of the lower channel. Shallow gravel bars in the vicinity of Brandy Bar (RM 20) also caused navigation hazards, and it was this area that ultimately became the reach of primary 20th and 21st century sand and gravel mining by Umpqua River Navigation Company and its successors.

Historical accounts also document channel and land-use practices that may have affected channel and bed-material conditions. These are most completely summarized in Beckham (1986) and include navigational dredging and rock removal, gold mining, instream gravel mining, impoundment for hydropower, and forestry and other land-use practices.

Historic navigation improvements were focused in the Tidal Reach, which has been the only section of river with extensive commercial boat traffic (Moser, 1976), but upstream reaches also had many rapids modified in the early 1870s in an attempt to promote navigation from the Pacific Ocean to Roseburg. Likewise, some bedrock rapids were modified in the late 19th century on both the South and North Umpqua Rivers to facilitate log drives (Beckham, 1986).

Mill dams and other small obstructions also served various needs of early settlers, and later, larger dams have provided for hydropower and flood control. Of these early dams near Kellogg (RM 70; Coast Range Reach), Roseburg (RM 123; Roseburg Reach), and Winchester (North Umpqua RM 7), only the Winchester Dam, a 16-ft-high concrete structure on the North Umpqua River, remains, but it probably does not significantly impede sediment movement. Pacific Power's North Umpqua Hydroelectric Project was constructed during 1952-55 and now traps bedload from the upstream 32 percent of the North Umpqua River basin. Sediment studies conducted in the late 1990s as part of relicensing these facilities are summarized later in this report. Galesville Reservoir on Cow Creek began filling in 1985, and since then has trapped all bed material from the upper $74.3 \mathrm{mi}^{2}$ of Cow Creek, encompassing 5.9 percent of the South Umpqua River basin at the Cow Creek confluence.

Gold mining in the Umpqua River basin began in 1852 on the South Umpqua River near Riddle and in lower Cow Creek (Beckham, 1986, p. 225-226). The widespread placer mining on the South Umpqua River and its tributaries Olalla Creek (fig. 5; a tributary of Lookinglass Creek), Myrtle Creek, Cow Creek, and Coffee Creek (Diller, 1914; Ramp, 1972) probably had the most significant effects on instream gravel conditions. All these drainages enter the South Umpqua River within the Days Creek and Roseburg Valley Reaches. Placer mining in the late 19th and early 20th centuries involved extensive excavation of alluvial terraces flanking the present watercourses, in places aided by elaborate hydraulic works (fig. 5). Beckham (1986, p. 93) suggested tremendous effects to the stream channels from these activities:

"Mining generated terrible problems for the Indians. The cascade of debris down the creeks and rivers had calamitous impact on the fish runs: mining destroyed the spawning grounds by washing away the gravels and coating the river bottom with mud.”

Such effects, as well as the possibly tremendous inputs of gravel to South Umpqua tributaries, may still have important implications for the present-day sediment conditions in the Umpqua River system. 


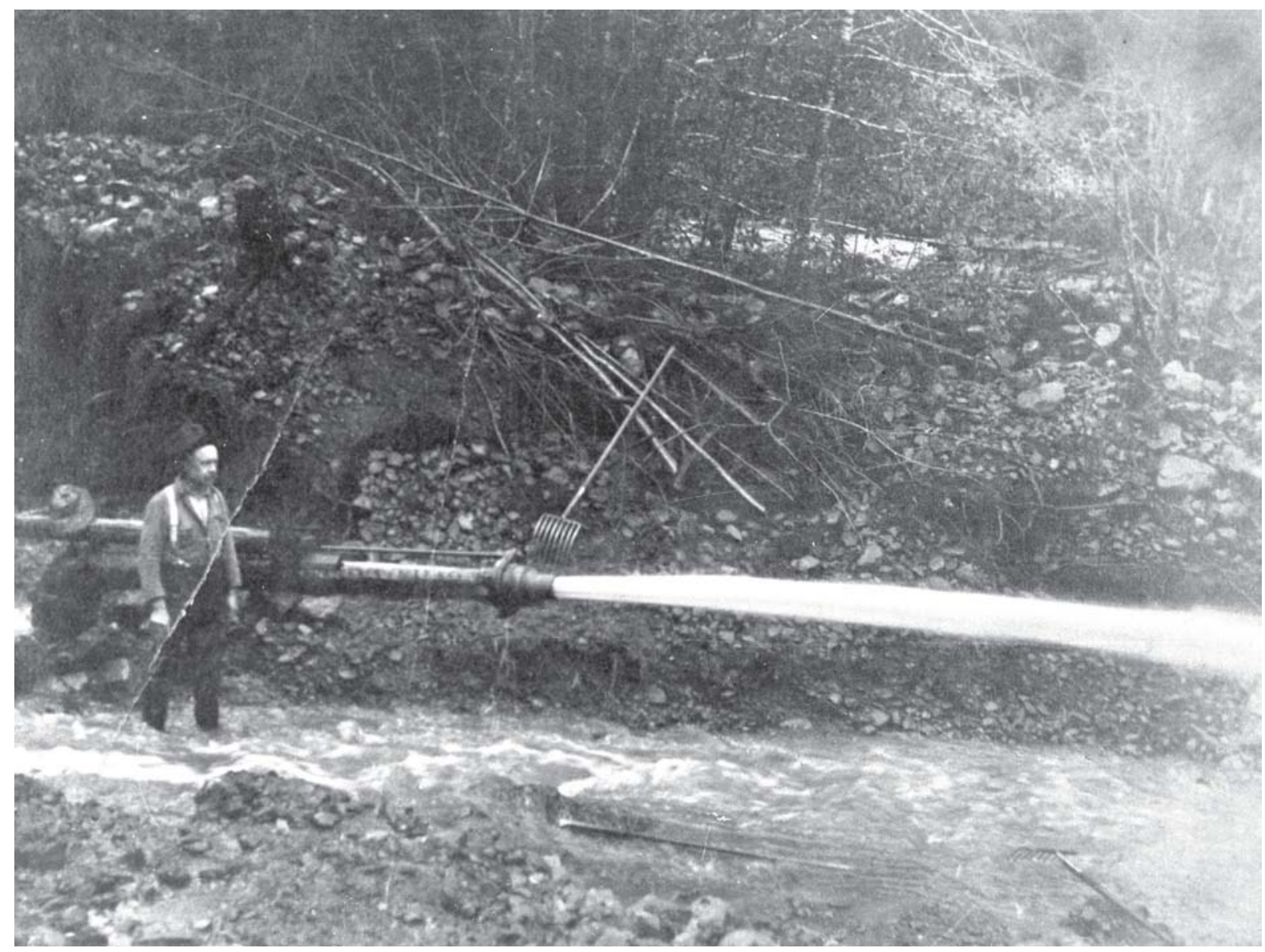

Figure 5. Hydraulic mining in the Olalla District, Lookingglass Creek drainage, Oregon. Courtesy of Douglas County Museum (Photograph N5155), undated.

\section{Compilation of Historical Maps and Survey Data}

Beginning in the mid-19th century, the Umpqua River has been mapped and surveyed by multiple agencies, providing a potentially rich set of data that could be used to evaluate historical channel change. A limited set of maps and profile surveys developed by the General Land Office (GLO), USGS, and Army Corps of Engineers were reviewed in this study and are summarized in table 2. In reviewing the maps, we aimed to determine whether they provided information regarding channel features (especially gravel bars) and bed elevations, and also to discern whether the map could be digitized for the purpose of conducting a future study comparing recent and historical channel morphology. 
Table 2. List of maps reviewed for this study of the Umpqua River basin, southwestern Oregon

[GLO, General Land Office; BLM, Bureau of Land Management; NOAA, National Oceanographic and Atmospheric Administration; OSU, Oregon State University; USGS, U.S. Geological Survey; USACE, U.S. Army Corps of Engineers; DOGAMI, Oregon Department of Geology and Mineral Industries]

\begin{tabular}{|c|c|c|c|c|c|}
\hline Map title or description & $\begin{array}{l}\text { Map } \\
\text { scale }\end{array}$ & $\begin{array}{l}\text { Map } \\
\text { date }\end{array}$ & $\begin{array}{l}\text { Survey or } \\
\text { Map } \\
\text { Source }\end{array}$ & Depository & Description \\
\hline General Land Office Surveys & $\sim 1: 31,680$ & $\begin{array}{l}1853- \\
1890 s\end{array}$ & GLO maps & $\begin{array}{l}\text { BLM website: } \\
\text { http://www.blm.gov/or/ } \\
\text { landrecords/survey/ySrvy1. } \\
\text { php; USGS (Portland, } \\
\text { Oregon) has copies. }\end{array}$ & $\begin{array}{l}\text { Earliest surveys conducted 1853-1858; } \\
\text { most maps were meandered in 1853, 1874, } \\
\text { and/ or } 1891 \text {. Maps show planview of river } \\
\text { channel and surrounding lands, limited } \\
\text { details on river features. }\end{array}$ \\
\hline $\begin{array}{l}\text { Preliminary Survey of the } \\
\text { Entrance to Umpquah River, } \\
\text { Oregon }\end{array}$ & $1: 20,000$ & 1854 & $\begin{array}{l}\text { United } \\
\text { States } \\
\text { Coast } \\
\text { Survey }\end{array}$ & $\begin{array}{l}\text { NOAA website: } \\
\text { http://historicalcharts. } \\
\text { noaa.gov/historical_jpgs/ } \\
\text { CP436C.jpg }\end{array}$ & Map of lower 5 miles of Umpqua River. \\
\hline $\begin{array}{l}\text { Profile surveys in } 1914 \text { in } \\
\text { Umpqua River Basin. U.S. } \\
\text { Geological Survey Water- } \\
\text { Supply Paper } 379\end{array}$ & $1: 31,680$ & 1914 & USGS & $\begin{array}{l}\text { OSU library, Corvallis } \\
\text { Oregon; USGS library, } \\
\text { Portland, Oregon }\end{array}$ & $\begin{array}{l}\text { Plan and profile of Umpqua River from } \\
\text { Elkton to confluence of North and South } \\
\text { forks and of North Umpqua to Boulder } \\
\text { Creek, Oregon ( } 11 \text { sheets). Plan and } \\
\text { profile of North Umpqua River from } \\
\text { Boulder Creek to Diamond Lake ( } 2 \\
\text { sheets). }\end{array}$ \\
\hline $\begin{array}{l}\text { Map of Umpqua River, } \\
\text { Scottsburg to Reedsport, } \\
\text { Oregon }\end{array}$ & $1: 20,000$ & 1921 & USACE & $\begin{array}{l}\text { Photocopies at USGS } \\
\text { (Portland, Oregon) and } \\
\text { other locations. }\end{array}$ & $\begin{array}{l}\text { Bathymetric map with low water } \\
\text { soundings;. }\end{array}$ \\
\hline $\begin{array}{l}\text { Examination of Umpqua River, } \\
\text { Oregon and entrance }\end{array}$ & Unknown & 1925 & USACE & $\begin{array}{l}\text { OSU library, Corvallis } \\
\text { Oregon }\end{array}$ & $\begin{array}{l}\text { Bathymetric map of lower } 3 \text { miles of } \\
\text { Umpqua River }\end{array}$ \\
\hline $\begin{array}{l}\text { Plan and Profile of Umpqua } \\
\text { River above Scottsburg, North } \\
\text { Umpqua River, and Tributaries }\end{array}$ & $1: 31,680$ & 1926 & USGS & $\begin{array}{l}\text { OSU library, Corvallis } \\
\text { Oregon }\end{array}$ & $\begin{array}{l}\text { Document includes nine sheets of contour } \\
\text { maps and longitudinal profiles. }\end{array}$ \\
\hline $\begin{array}{l}\text { Plan and Profile of South } \\
\text { Umpqua River, Oregon, from a } \\
\text { Point near Days Creek to Mile } \\
26 \text { and Tributaries. Dam sites. }\end{array}$ & Varies & 1938 & USGS & $\begin{array}{l}\text { OSU library, Corvallis } \\
\text { Oregon }\end{array}$ & $\begin{array}{l}\text { Contour map of South Umpqua from Days } \\
\text { Creek area to Francis Creek, above Milo. } \\
\text { Includes profiles. }\end{array}$ \\
\hline $\begin{array}{l}\text { Plan and Profile map of Cow } \\
\text { Creek, Oregon from Sec } 2 . \text { T. } \\
32 \text { S., R. } 4 \text { W to Sec. } 2 . \text { T.32 } \\
\text { S., R.3 W. Dam Sites }\end{array}$ & $1: 24,000$ & 1939 & USGS & $\begin{array}{l}\text { OSU library, Corvallis } \\
\text { Oregon }\end{array}$ & $\begin{array}{l}\text { Contour map of Cow Creek from Glendale } \\
\text { area to Applegate Creek, including dam } \\
\text { sites. }\end{array}$ \\
\hline $\begin{array}{l}\text { Report on Reexamination of } \\
\text { Umpqua River and Harbor, } \\
\text { Oregon }\end{array}$ & Unknown & 1939 & USACE & $\begin{array}{l}\text { OSU library, Corvallis } \\
\text { Oregon }\end{array}$ & $\begin{array}{l}\text { Bathymetric map of lower } 12 \text { miles of } \\
\text { Umpqua River; shows location of islands, } \\
\text { bars, soundings etc. }\end{array}$ \\
\hline $\begin{array}{l}\text { Plan Dam Sites, Smith River, } \\
\text { Oregon }\end{array}$ & $1: 24,000$ & 1958 & USGS & $\begin{array}{l}\text { OSU library, Corvallis } \\
\text { Oregon }\end{array}$ & $\begin{array}{l}\text { Planview of three dam sites on Smith } \\
\text { River near Gardiner. }\end{array}$ \\
\hline $\begin{array}{l}\text { Plan Bradley Creek Reservoir } \\
\text { and Dam Site North Umpqua } \\
\text { River }\end{array}$ & $1: 24,000$ & 1962 & USGS & $\begin{array}{l}\text { OSU library, Corvallis } \\
\text { Oregon }\end{array}$ & $\begin{array}{l}\text { Planview contour map of Bradley Creek } \\
\text { damsite. Also shows area and capacity } \\
\text { curves. }\end{array}$ \\
\hline $\begin{array}{l}\text { Geologic Compilation Map of } \\
\text { Douglas County, Oregon }\end{array}$ & $1: 250,000$ & 1972 & DOGAMI & $\begin{array}{l}\text { PDF available from } \\
\text { DOGAMI, Portland, } \\
\text { Oregon }\end{array}$ & $\begin{array}{l}\text { Map shows major geological units and } \\
\text { geomorphic divisions. }\end{array}$ \\
\hline $\begin{array}{l}\text { Flood profiles in the Umpqua } \\
\text { River Basin, Oregon (three } \\
\text { parts) }\end{array}$ & Varies & $\begin{array}{l}1972 \\
1973 \\
1975\end{array}$ & USGS & $\begin{array}{l}\text { USGS library, Portland, } \\
\text { Oregon }\end{array}$ & $\begin{array}{l}\text { Series of three reports (Oster, 1972; 1973; } \\
\text { 1975) provide cross-sections and flood } \\
\text { profiles for Umpqua, North Umpqua, and } \\
\text { South Umpqua Rivers and selected } \\
\text { tributaries. Elevation data from } \\
\text { orthophotography and soundings. }\end{array}$ \\
\hline
\end{tabular}


A series of USGS flood studies (Oster, 1972; 1973; 1975) and early navigational surveys completed by the U.S. Army Corps of Engineers produced maps that potentially provide useful information. The USGS flood studies provide longitudinal profiles and cross-sections for the Umpqua River, South Umpqua River, North Umpqua River, and select tributaries. The USGS data were originally used for flood modeling, but could provide baseline topographic information for evaluating systemwide changes in channel geometry from the 1970s to present. The navigational surveys from the late 19th and early 20th centuries primarily cover the tidal reach of the Umpqua River where navigation improvement efforts were focused. Depending on the availability, extent, and data quality of additional navigational surveys not reviewed in this study, it may be possible to compile a set of maps covering the Tidal Reach (RM 0-27.5) that span several decades in the time period 1850-1920. Such maps could be used to evaluate changes in bed elevation in the early phases of European-American occupation in the Umpqua River basin and may help to place 20th century bathymetric changes in a greater historical context, possibly revealing longer term patterns of incision and aggradation in the lower reaches of the Umpqua River.

\section{Assessment of Aerial Photographs}

We reviewed aerial photograph collections from the Corps of Engineers library in Portland and the University of Oregon library in Eugene, as well as digital orthophotographs available from online sources (table 3). Additional aerial photographs not included in this review are likely available from the Bureau of Land Management, National Archives, and other sources.

Table 3. List of aerial photographs reviewed for this study of the Umpqua River basin, southwestern Oregon

[USACE, U.S. Army Corps of Engineers; UO, University of Oregon; USDA, U.S. Department of Agriculture; USGS, U.S. Geological Survey; OR DOR, Oregon Department of Revenue; BLM, Bureau of Land Management; NAIP, National Agriculture Imagery Program]

\begin{tabular}{|c|c|c|c|c|}
\hline Year & Area covered & Scale & Source & Current location \\
\hline \multicolumn{5}{|c|}{ Umpqua River, river mile 0-112 } \\
\hline 1939 & Mouth to Reedsport & $1: 20,000$ & USACE & UO Library \\
\hline 1939 & $\begin{array}{l}\text { Nearly complete Quads for } \\
\text { Reedsport to Elkton }\end{array}$ & $1: 10,200$ & USACE & USACE, Portland District \\
\hline 1939 & Elkton upstream & $1: 20,000$ & USDA & UO Library \\
\hline 1942 & Mouth to upstream of Scottsburg & $1: 20,000$ & USGS & UO Library \\
\hline 1943 & Elkton to Myrtle Creek & $1: 20,000$ & USACE & UO Library \\
\hline 1944 & Mouth to Reedsport & $\begin{array}{l}1: 15,000 / \\
1: 30,000\end{array}$ & USACE & USACE, Portland District \\
\hline 1950 & Full coverage & $1: 20,000$ & USGS & UO Library \\
\hline 1952 & Mouth to Elkton & $1: 20,000$ & USDA & UO Library \\
\hline $1956-57$ & $\begin{array}{l}\text { Nearly complete coverage RM } \\
\text { 8-16 }\end{array}$ & various & USACE & USACE, Portland District \\
\hline 1957 & $\begin{array}{l}\text { Partial coverage in RM 8-16, } \\
\text { RM 24-33 and RM 45-49 }\end{array}$ & $\begin{array}{l}1: 9,600 / \\
1: 24,000\end{array}$ & USACE & USACE, Portland District \\
\hline 1960 & $\begin{array}{l}\text { Downstream of Elkton to points } \\
\text { upstream }\end{array}$ & $1: 20,000$ & USDA & UO Library \\
\hline 1963 & Mouth to Reedsport & various & USACE & USACE, Portland District \\
\hline 1963-64 & Downstream of Elkton & $1: 14,400$ & USACE & USACE, Portland District \\
\hline
\end{tabular}


Table 3. List of aerial photographs reviewed for this study of the Umpqua River basin, southwestern Oregon-continued

[USACE, U.S. Army Corps of Engineers; UO, University of Oregon; USDA, U.S. Department of Agriculture; USGS, U.S. Geological Survey; OR DOR, Oregon Department of Revenue; BLM, Bureau of Land Management; NAIP, National Agriculture Imagery Program]

\begin{tabular}{|c|c|c|c|c|}
\hline Year & Area covered & Scale & Source & Current location \\
\hline \multicolumn{5}{|c|}{ Umpqua River, river mile 0-112 } \\
\hline 1965 & Nearly complete coverage & various & USACE & USACE, Portland District \\
\hline 1967 & Full coverage & $1: 20,000$ & USDA & UO Library \\
\hline 1969 & Downstream of Elkton & $1: 20,000$ & OR DOR & UO Library \\
\hline 1973 & $\begin{array}{l}\text { Downstream of Roseburg to } \\
\text { mouth of N. Umpqua River }\end{array}$ & $1: 20,000$ & OR DOR & UO Library \\
\hline 1974-75 & Mouth to Reedsport & $\begin{array}{c}1: 24,000 / \\
1: 2,400\end{array}$ & USACE & USACE, Portland District \\
\hline 1977 & Mouth to Reedsport & $1: 15,000$ & USACE & USACE, Portland District \\
\hline 1978 & Mouth to Scottsburg & $1: 12,000$ & USACE & USACE, Portland District \\
\hline 1978 & $\begin{array}{l}\text { Scottsburg area (RM } 24 \text { to RM } \\
\text { 33) }\end{array}$ & $1: 24,000$ & USACE & USACE, Portland District \\
\hline 1979 & $\begin{array}{l}\text { Points: near Reedsport, Elkton, } \\
\text { near Roseburg and Myrtle Creek }\end{array}$ & $1: 20,000$ & USDA & UO Library \\
\hline 1980 & Gardiner area (RM 8 to RM 16) & $1: 12,000$ & USACE & USACE, Portland District \\
\hline 1980 & Mouth to Scottsburg & $1: 20,000$ & USGS & UO Library \\
\hline 1980 & Mouth to Scottsburg & $1: 12,000$ & USACE & USACE, Portland District \\
\hline 1982 & Gardiner area (RM 8 to RM 16) & $1: 24,000$ & USACE & USACE, Portland District \\
\hline 1982 & Nearly complete coverage & $1: 48,000$ & USACE & USACE, Portland District \\
\hline 1984 & Point near Elkton & $1: 20,000$ & USGS & UO Library \\
\hline 1985 & $\begin{array}{l}\text { Downstream of Elkton to Tyee } \\
\text { area }\end{array}$ & $1: 20,000$ & BLM & UO Library \\
\hline 1986 & $\begin{array}{l}\text { Partial coverage near Scottsburg, } \\
\text { Elkton, and Tyee }\end{array}$ & $1: 48,000$ & USACE & USACE, Portland District \\
\hline 1989 & Tyee area (RM 81 to RM 100) & $1: 24,000$ & USACE & USACE, Portland District \\
\hline 1989 & Elkton to Roseburg & $1: 20,000$ & BLM & UO Library \\
\hline 1989 & $\begin{array}{l}\text { Scottsburg area (RM } 24 \text { to RM } \\
\text { 33) }\end{array}$ & $1: 12,000$ & USACE & USACE, Portland District \\
\hline 1989 & Full coverage & $1: 24,000$ & USACE & USACE, Portland District \\
\hline 1995 & Full coverage & $1: 20,000$ & USGS & http://edcns17.cr.usgs.gov/EarthExplorer/ \\
\hline 2000 & Full coverage & $1: 20,000$ & USGS & http://edcns17.cr.usgs.gov/EarthExplorer/ \\
\hline 2001 & Scottsburg downstream & $1: 24,000$ & USACE & USACE, Portland District \\
\hline 2001 & Coverage from RM 8 to RM 16 & $1: 24,000$ & USACE & USACE, Portland District \\
\hline 2002 & Partial coverage Tyee upstream & $1: 24,000$ & USACE & USACE, Portland District \\
\hline 2003 & Coverage from RM 8 to RM 16 & $1: 2,400$ & USACE & USACE, Portland District \\
\hline 2004 & Full coverage & $1: 20,400$ & $\begin{array}{l}\text { Douglas } \\
\text { County }\end{array}$ & Douglas County \\
\hline 2005 & Full coverage & $1: 20,000$ & USDA & $\begin{array}{l}\text { http://www.oregonexplorer.info/imagery/ } \\
\text { about/about.aspx?Res }=17270\end{array}$ \\
\hline
\end{tabular}


Table 3. List of aerial photographs reviewed for this study of the Umpqua River basin, southwestern Oregon-continued

[USACE, U.S. Army Corps of Engineers; UO, University of Oregon; USDA, U.S. Department of Agriculture; USGS, U.S. Geological Survey; OR DOR, Oregon Department of Revenue; BLM, Bureau of Land Management; NAIP, National Agriculture Imagery Program]

\begin{tabular}{llrll}
\hline Year & \multicolumn{1}{c}{ Area covered } & Scale & Source & \multicolumn{1}{c}{ Current location } \\
\hline \multicolumn{4}{c}{ North Umpqua River, river mile 0-36 } \\
\hline 1939 & Mouth to Glide & $1: 20,000$ & USDA & UO Library \\
1950 & Full coverage & $1: 20,000$ & USGS & UO Library \\
1953 & Myrtle Creek to River Forks & $1: 20,000$ & USDA & UO Library \\
1954 & Coverage from Brockway Gage & $1: 20,000$ & USDA & UO Library \\
& to Myrtle Creek & & & \\
1957 & Full coverage & $1: 96,000$ & USACE & USACE, Portland District \\
1960 & Full coverage & $1: 20,000$ & USDA & UO Library \\
1965 & Nearly complete coverage & $1: 24,000$ & USACE & USACE, Portland District \\
1967 & Full coverage & $1: 20,000$ & USDA & UO Library \\
1973 & Point near Winchester & $1: 20,000$ & OR DOR & UO Library \\
1979 & Points: near Winchester & $1: 20,000$ & USDA & UO Library \\
1982 & Mouth to Winchester & $1: 48,000$ & USACE & USACE, Portland District \\
1985 & Full coverage & $1: 20,000$ & BLM & UO Library \\
1995 & Full coverage & $1: 20,000$ & USGS & http://www.oregon.gov/DAS/EISPD/GEO/ \\
& & & & data/doq.shtml \\
2000 & Full coverage & $1: 20,000$ & USGS & http://edcsns17.cr.usgs.gov/EarthExplorer/ \\
2002 & Full coverage & $1: 24,000$ & USACE & USACE, Portland District \\
2004 & Full coverage & $1: 20,400$ & Douglas & Douglas County \\
& & & County & \\
2005 & Full coverage & $1: 20,000$ & NAIP & http://165.221.201.14/NAIP.html
\end{tabular}

South Umpqua River, river mile 112-192

\begin{tabular}{lllll}
\hline 1939 & Mouth to Tiller & $1: 20,000$ & USDA & UO Library \\
1950 & Full coverage & $1: 20,000$ & USGS & UO Library \\
1953 & Mouth to point downstream of & $1: 20,000$ & USDA & UO Library \\
& Tiller & & & \\
1957 & Full coverage & Varies & USACE & USACE, Portland District \\
1960 & Full coverage & $1: 20,000$ & USDA & UO Library \\
1965 & Full coverage & $1: 24,000$ & USACE & USACE, Portland District \\
1967 & Full coverage & $1: 20,000$ & USDA & UO Library \\
1968 & Full coverage above Days Creek & $1: 40,000$ & USACE & USACE, Portland District \\
1971 & Full coverage & $1: 20,000$ & BLM & UO Library \\
1977 & Partial coverage: Canyonville, & $1: 4,800$ & USACE & USACE, Portland District \\
& Days Creek to Tiller & & & \\
1979 & Points near Canyonville & $1: 20,000$ & USDA & UO Library \\
1982 & Full coverage & $1: 48,000$ & USACE & USACE, Portland District \\
1985 & Full coverage & $1: 20,000$ & BLM & UO Library \\
1986 & Full coverage & $1: 48,000$ & USACE & USACE, Portland District \\
1989 & Full coverage & $1: 24,000$ & BLM & UO Library
\end{tabular}


Table 3. List of aerial photographs reviewed for this study of the Umpqua River basin, southwestern Oregon-continued

[USACE, U.S. Army Corps of Engineers; UO, University of Oregon; USDA, U.S. Department of Agriculture; USGS, U.S. Geological Survey; OR DOR, Oregon Department of Revenue; BLM, Bureau of Land Management; NAIP, National Agriculture Imagery Program]

\begin{tabular}{|c|c|c|c|c|}
\hline Year & Area covered & Scale & Source & Current location \\
\hline \multicolumn{5}{|c|}{ South Umpqua River, river mile 112-192 } \\
\hline 1995 & Full coverage & $1: 20,000$ & USGS & http://edcsns17.cr.usgs.gov/EarthExplorer \\
\hline 2000 & Full coverage & $1: 20,000$ & USGS & http://edcsns17.cr.usgs.gov/EarthExplorer/ \\
\hline 2002 & Full coverage & $1: 24,000$ & USACE & USACE, Portland District \\
\hline 2004 & Full coverage & $1: 20,400$ & $\begin{array}{l}\text { Douglas } \\
\text { County }\end{array}$ & Douglas County \\
\hline 2005 & Full coverage & $1: 20,000$ & NAIP & http://165.221.201.14/NAIP.html \\
\hline
\end{tabular}

Several sets of aerial photographs are available that cover most or all of the study area. Along the alluvial reaches of the North and South Umpqua Rivers, including the Roseburg, Days Creek, and North Umpqua Reaches, there is nearly complete aerial photograph coverage every 1-10 years from 1939 to 2005. The Tidal Reach of the mainstem Umpqua River (RM 0-27.5) also has frequent aerial photograph coverage, but the reach from Elkton to the confluence of the North and South Umpqua (RM 48.5-112; the Coast Range and Garden Valley Reaches), has sparser coverage, both in terms of the temporal frequency of the photographic sets and their spatial coverage. Photographic sets from 1939, 1950, 1967, and several more recent years apparently cover the entire study area. In summary, these collections of aerial photographs could provide a solid basis for documenting historic changes to channel and gravel bar conditions, although such analyses might not reveal changes resulting from recent changes in land-use practices because of lengthy response-time lags.

\section{Review of Water- and Sediment-Related Studies in the Umpqua River Basin}

We also reviewed previous studies of hydrology and sediment transport that have been conducted in the Umpqua River basin. Although there are numerous studies peripherally related to bedmaterial supply and transport (such as turbidity and other water-quality studies), we focused on two studies directly relevant to issues of gravel transport and channel morphology in the study area: (1) the basinwide analysis of sediment transport by Curtiss (1975), and (2) the sediment transport analyses conducted by Stillwater Sciences (2000) in support of the FERC relicensing of the Pacific Power hydroelectric facilities on the North Umpqua River.

The Curtiss (1975) report builds on an earlier USGS report by Onions (1969) by providing estimates of annual suspended-sediment discharge for 11 sites in the Umpqua River basin based on as many as 18 years of suspended-sediment measurements between 1956 and 1973. Although there were no measurements of bedload in this study, Curtiss (1975) calculated total sediment loads (bedload plus suspended load) on the basis of measurements at Flynn Creek (a Coast Range stream in the Alsea River basin) where bedload constituted 3 percent of the mean annual suspended-sediment yield. This ratio was applied for the sites in the Umpqua River basin, except for Cow Creek, where field observations led to the inference that bedload composed 5 percent of the total load. Although no known bedload measurements for the Umpqua River system substantiate these values, bedload transport rates typically scale with suspended load, and the analysis by Curtiss (1975) probably provides a reasonable guide to the relative contributions of bed material to the Umpqua River system. For the mean annual total sediment discharge of $1.7 \times 10^{6}$ tons/yr of the South Umpqua River (at Brockway), the Curtiss (1975) analysis indicates that $0.31 \times 10^{6}$ tons/yr enters via Lookingglass Creek, $0.37 \times 10^{6}$ tons/yr joins at Cow 
Creek, and $0.14 \times 10^{6}$ tons/yr comes from the upper watershed upstream of the Tiller gaging station. These values suggest that more than 90 percent of the sediment entering the South Umpqua River is derived from tributaries joining downstream of Tiller. At the Elkton streamflow-gaging station on the mainstem Umpqua River, where $3.5 \times 10^{6}$ tons/yr of sediment passes each year, 23 percent is from the North Umpqua River $\left(0.80 \times 10^{6}\right.$ tons/yr at Winchester $), 49$ percent from the South Umpqua River at Brockway $\left(1.7 \times 10^{6}\right.$ tons/yr), 5 percent from the Calapooya $\left(0.19 \times 10^{6}\right.$ tons/yr), with the balance likely from the lower South Umpqua River and unmeasured tributaries entering the mainstem Umpqua River between the confluence of the North and South Umpqua Rivers and the Elkton streamflow-gaging station. These results point to the overall greater contribution of sediment to the Umpqua River system by the South Umpqua River. The data could also serve as a basis for a calibrated model of basin sediment production similar to that done for the Deschutes River basin in central Oregon (O'Connor and others, 2003).

Stillwater Sciences (2000) prepared sediment budgets for the North Umpqua River to assess the role of Pacific Power's North Umpqua River hydroelectric project on North Umpqua River sediment conditions. Their analysis incorporated a reanalysis of the suspended load data summarized by Curtiss (1975), analysis of reservoir sedimentation data, estimates of geomorphic process rates, landslide inventory information, and GIS analyses. They concluded that the dams on the North Umpqua River trap all bedload from the upper 32 percent of the North Umpqua River basin but the effects of this bedmaterial sediment reduction on downstream reaches are more than compensated by enhanced sediment production owing to 20th century land-use practices - primarily forest practices - and the effects of the 1964 flood. Specifically, Stillwater Sciences (2000) postulated that downstream of Steamboat Creek, at North Umpqua RM 49.2, the effects of land use doubled the average annual bedload flux to 18,000 tons/yr , from a "reference condition" (pre-1950, minimal land-use effects) value of less than 9,000 tons/yr, despite total bed-material blockage since 1952 at Soda Springs Dam at RM 69.3. Although these conclusions for the North Umpqua River remain unverified, the possibility of enhanced bed material contributions to the Umpqua River system from increased sediment yield in managed lands basinwide would need to be addressed for comprehensive understanding long-term bed-material supply and transport conditions.

\section{Review of Gravel-Operator Surveys}

Survey data for 2001-03 through June 2008 for six instream gravel mining sites along the South Umpqua River in the Roseburg and Days Creek reaches were provided by Umpqua Sand and Gravel Inc. and Knife River/LTM Inc. (IE Engineering, written commun., 2008). Surveyed cross-sections and longitudinal profiles for the Tidal Reach of Umpqua River near the LTM Inc. dredging at RM 19-22 were provided by Lidstone and Associates and also were included in correspondence provided by Janine Castro (U.S. Fish and Wildlife Service; written commun., 2008). Although the South Umpqua River mining surveys reviewed in this study (fig. 6) are incomplete and represent just a portion of the total permitted gravel extraction occurring in the Umpqua River basin, they do show the evolution of individual gravel bars in the years following gravel extraction. 


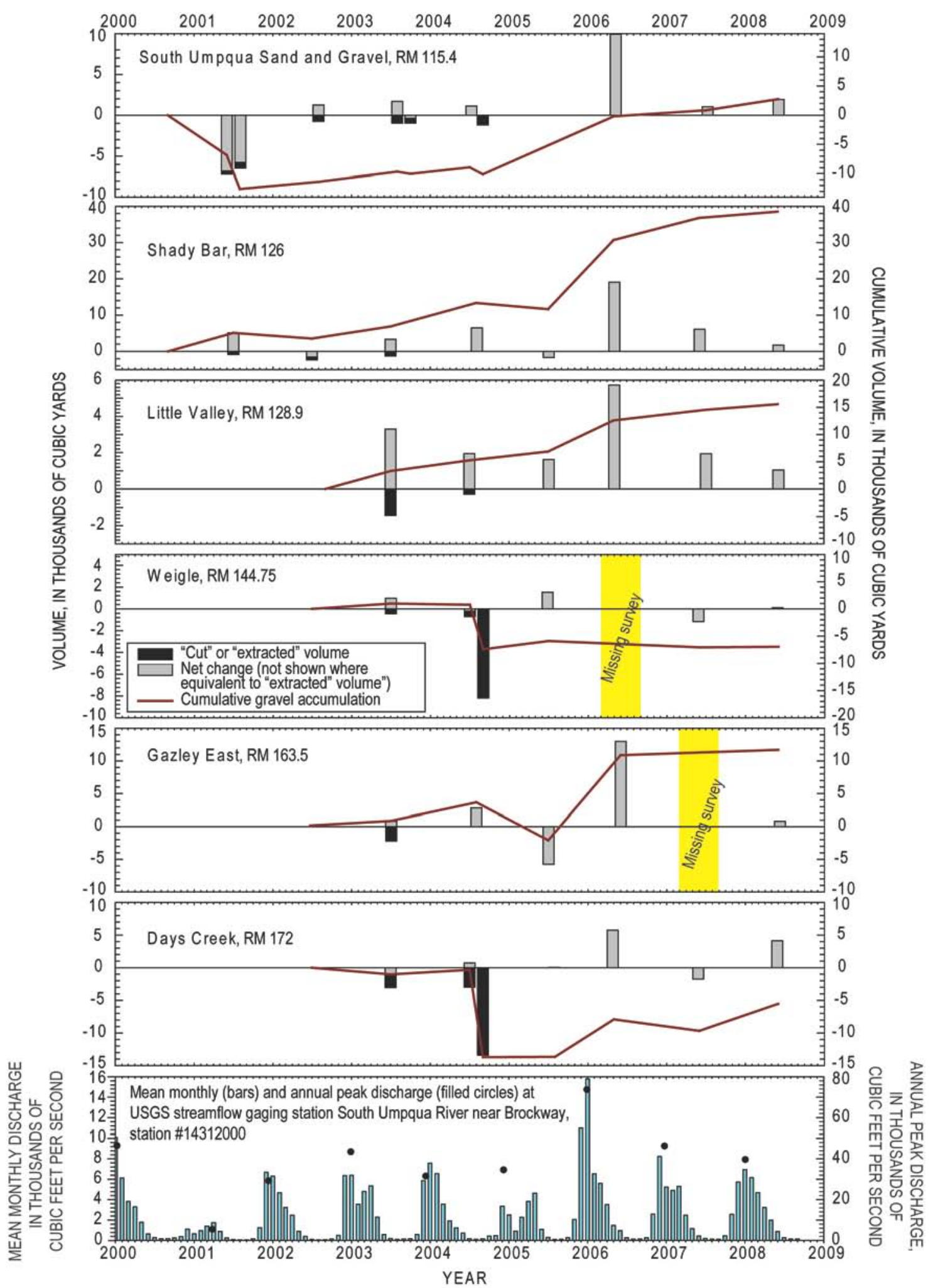

Figure 6. Summary of gravel bar volume changes, 2000-2008, at instream gravel mining sites along the South Umpqua River, southwestern Oregon. Data from surveys provided by IE Engineering, Roseburg, Oregon (written commun., 2008). For sites with missing surveys, cumulative totals assume no net change for period of missing data. Mean monthly and annual (water year) peak flows are from USGS data for streamflow-gaging station South Umpqua River near Brockway, station 14312000. 
Survey information for the six sites of gravel bar mining on the South Umpqua River show that removal volumes in 2001-04 ranged up to 13,390 $\mathrm{yd}^{3}$ but typically were less than $10,000 \mathrm{yd}^{3}$ per year at each site. From these records and communication with individual operators, none of the analyzed bars have been mined after 2004. Since then, each of the six bars has accumulated gravel, with four of the six bars now showing positive balances relative to the original provided survey (and it is possible the Weigle Bar also has had a net accumulation because survey data spanning the 2006 high flow was not available). Deposition volumes are most easily assessed for 2004-08, during which there was no mining and all changes to bar volumes resulted from fluvial erosion and deposition. Nearly all bars grew significantly (aggrading as much as $2 \mathrm{ft}$ ) during the winter of 2005-06, in conjunction with high flows, including the Dec. 31, 2005, peak of 73,400 $\mathrm{ft}^{3} / \mathrm{s}$ - the highest peak flow on the South Umpqua River since December 1996. The only bar that clearly has not regained the volume of sediment documented in the first survey is Days Creek bar at RM 172. In all cases, the net changes in volumes, averaged over our mapping of bar area, total less than $1 \mathrm{ft}$ of bar-surface elevation change.

These surveys on the sites on the South Umpqua River show that active gravel transport by the river tends to rebuild the forms of mined gravel bars, especially after large flows and multiple years of no mining. But because these mined gravel bars have enhanced depositional space resulting from excavation, they are likely to preferentially accumulate gravel after mining and the survey results can not be used directly to determine long-term gravel accumulation or flux rates, although the survey data for the last few years may help provide bounds for such determinations. Also, since the first surveys post-date a long history of mining at many of these bars, long-term trends of bar changes and current bar status relative to undisturbed conditions cannot be determined directly from the surveys, although cursory analysis of systematic changes in bar area (described below) also indicates little overall change during 1939-2005. Nevertheless, extraction of gravel from these bars-in some years totaling more than $35,000 \mathrm{yd}^{3}$ for the six bars evaluated here-certainly reduces the overall flux of bed material through the river. Whether or not such volumes are significant relative to the overall bed-material transport and therefore affect long-term channel conditions for these reaches and downstream remains unanswered.

The Tidal Reach between RM 0 and 27.5 has experienced substantial bed-sediment removal to maintain navigation depths in the channel and for sand and gravel aggregate, summing to more than 1.2 million $\mathrm{yd}^{3}$ for 1949-2002 (fig. 7). The main area of aggregate removal has been between RM 19 and 22, where extraction has averaged about $175,000 \mathrm{yd}^{3} / \mathrm{yr}$ by the Umpqua River Navigation Company and its successors. Targeted analyses of the reach of aggregate mining in the 1970s (CH2M-Hill, 1971) and subsequently by Lidstone and Associates (written commun., 2008) and Janine Castro (U.S. Fish and Wildlife Service, written commun., 2008) also furnish repeat cross sections, channel soundings and thalweg profiles. Inspection of these data indicate that this reach is dynamic, with areas of deepening and shoaling, but that the general trends for most time sequences is channel deepening along the thalweg, locally as much as $5 \mathrm{ft}$, with areas of dredging not being refilled. In the case of the 1971 CH2M-Hill analysis, excavations in areas not mined for more than 5 years had not been refilled. Our preliminary interpretation of these observations is that the supply of bed material is less than the $175,000 \mathrm{yd}^{3}$ average annual bed-material removal rate. This value, however, is not directly comparable with bed-material transport values for other reaches because the much lower channel gradient of the Tidal Reach probably results in a larger proportion of the upstream derived sediment load — which is primarily transported as suspended load—becoming bedload in this reach of lower flow velocities and channel gradient. 


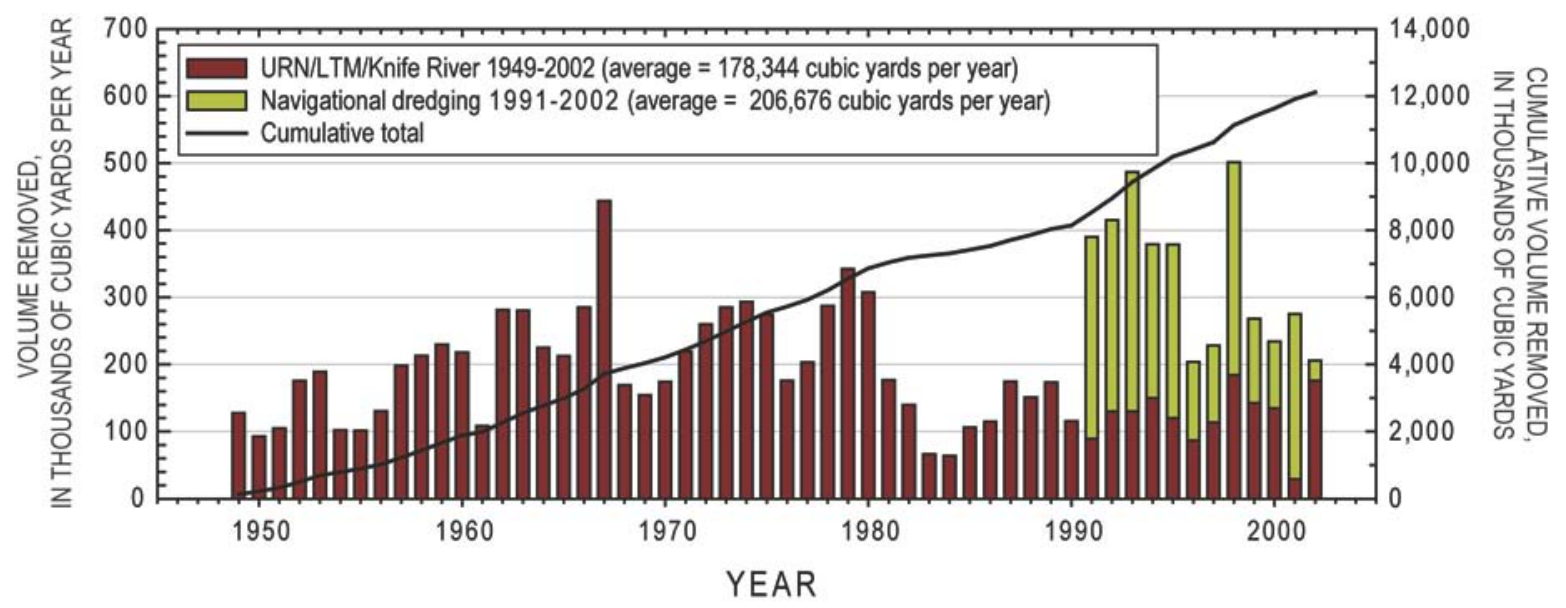

Figure 7. Excavation volumes for 1949-2002, for the Umpqua River Navigation (and successor companies) mining site along lower Umpqua River below RM 27, southwestern Oregon. Volumes for 1949-71 as reported by CH2M HILL (1971); Volumes for 1971-2002 from Umpqua River Dredging reports, as supplied by Lidstone and Associates (written commun., 2008).

\section{Compile and Review Oregon Department of Transportation Umpqua River Bridge Inspection Reports}

The Oregon Department of Transportation conducts routine inspections on bridges which provide information that is potentially useful in characterizing channel change at the bridge location. We reviewed 35 reports for inspections conducted between 2002 and 2008 for bridges crossing the Umpqua River, North Umpqua River, and South Umpqua River (Oregon Department of Transportation, written commun., 2008). For each of these, we evaluated the underwater reports, scour assessments, photographs, and any other notes or cross-section data providing an indication of incision or aggradation.

For nearly all bridges evaluated in the 35 bridge inspection reports we reviewed, all bridge piers have been set in bedrock. Although most piers show some scour near the footings, there were only three reports that describe substantial bedrock erosion near the piers. Cross-section data from multiple time periods were available for eight bridges within the study area. For six of these bridges, net change in thalweg elevation over time has been minimal, whereas at two locations, thalweg elevations have increased. The channel under the Highway 101 bridge near RM 11 on the Umpqua River (near the Smith River confluence in the Tidal Reach) aggraded about $5 \mathrm{ft}$ between 1999 and 2006, and South Umpqua River under the I-5 bridge near Roseburg (RM 122) aggraded about $2 \mathrm{ft}$ between 2000 and 2005. In summary, the bridge inspection reports reviewed so far do not indicate significant channel changes that can be linked to changes in sediment supply, primarily because most bridge crossings were located where piers could be placed directly into bedrock. The local degree of bedrock erosion near some of these piers, however, attests to the softness of local rock types, which might be an important factor in the apparent downstream decrease in gravel along the Umpqua River, particularly downstream of the confluence of the North and South Umpqua Rivers. More extensive research of the bridge inspection reports will not likely provide much useful information.

\section{Specific Gage Analysis}

Following the approach of Klingeman (1973), a specific gage analysis was completed for three USGS streamflow-gaging stations in the study area. The purpose of the specific gage analysis is to detect changes in streambed elevation by assessing changes in water elevation (stage) through time for a 
set of discharge values. At USGS streamflow-gaging stations, discharge is related to stage by a stagedischarge rating curve, which is based on multiple simultaneous measurements of stage and discharge. If channel conditions change substantially (as evidenced by consistent offsets of newer measurements from established rating curves), or if a station is moved, a new rating curve will be developed. The specific gage analysis evaluates trends as indicated by the sequence of rating curves for individual stations while they are at specific locations. For this study, we examined the sequence of USGS rating curves at three sites (fig. 8): the mainstem Umpqua River near Elkton (14321000), the South Umpqua River near Brockway (14312000), and the North Umpqua River at Winchester (14319500). Because the purpose of this task was to detect potentially small changes in bed elevation, we assessed changes in flow stage for low to moderate flows (500-10,000 $\mathrm{ft}^{3} / \mathrm{s}$ ), which are more sensitive to minor adjustments in bed elevation and are less likely to be influenced by temporal changes in bank vegetation or changes in bank shape. 

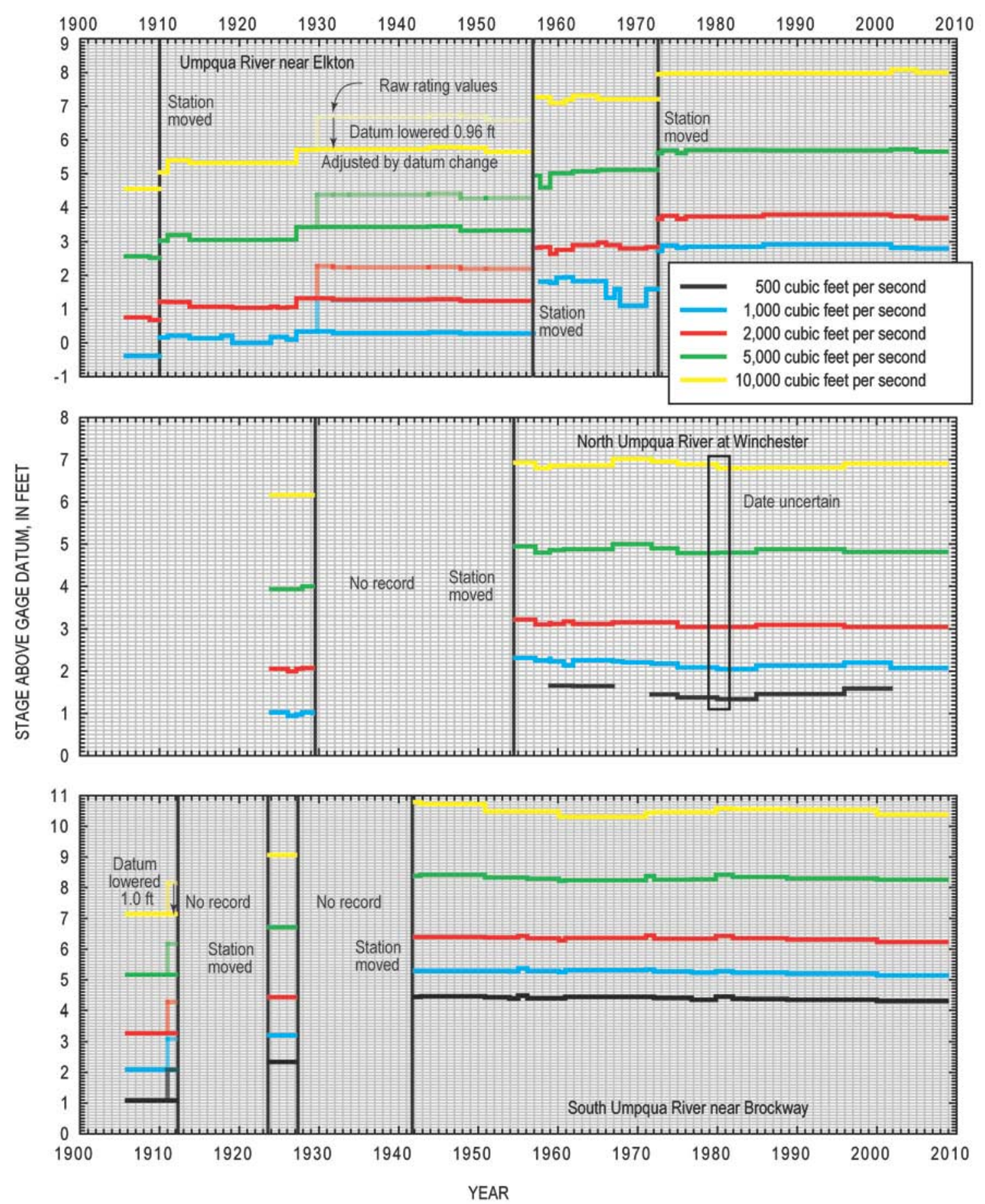

Figure 8. Sequence of stage-discharge rating curve elevations for specific discharges for long-term mainstem streamflow gages in Umpqua River, Oregon, study area. Source information from station records housed at Oregon Water Science Center, U.S. Geological Survey, Portland, Oregon.

The specific gage analysis (fig. 8) shows that all three sites have experienced minor changes in stage over the period for which flow data are available. At the Umpqua River station near Elkton, the gage location has changed four times over the period 1906-2008, and stage remained stable while at each location. For 1906-57, stage for each discharge varied by less than $0.4 \mathrm{ft}$, whereas during 1957-72, stage at $500 \mathrm{ft}^{3} / \mathrm{s}$ decreased by approximately $0.7 \mathrm{ft}$. This degradation may have resulted from local 
scouring of bed material, possibly associated with the 1964 flood. For 1972-2008, stage for all discharges remained nearly constant, indicating negligible change in bed elevation.

The gage analysis for the North Umpqua River at Winchester spans two time intervals: 1924-30 and 1955-2008. For all discharges, and across both time periods, measured stage varied by less than 0.4 $\mathrm{ft}$, indicating that the bed elevation at the Winchester gaging station has remained fairly constant over the period of measurement.

The South Umpqua gaging station near Brockway provides data for three periods: 1906-12, 1924-28, and 1942-2008. For all three time periods, the Brockway gage displays little to no change in stage for the discharges used in this analysis. For 1942-2008, the net change for 500 and 1,000 $\mathrm{ft}^{3} / \mathrm{s}$ is on the order of $0.2 \mathrm{ft}$, which indicates that the bed elevation at this site has remained fairly constant over time.

\section{Mapping of Gravel Bars and Channel Features}

Two mapping efforts were undertaken in order to identify spatial and temporal patterns in gravel bar location and size throughout the study area. As a first step, all river-flanking sediment accumulations throughout the study area were mapped and digitized from the 2005 National Agriculture Imagery Program (NAIP) orthophotographs at a scale of approximately 1:5,000 (fig. 9). For all study reaches except for the Tidal Reach, these areas consisted of gravel bars or patches of sand and gravel adjacent or within the channel. For the Tidal Reach, mapped accumulations included sand and gravel bars as well as extensive mud and tidal flats in the estuary. A more detailed mapping effort was conducted for five short reaches in order to evaluate possible temporal changes in gravel bar area.

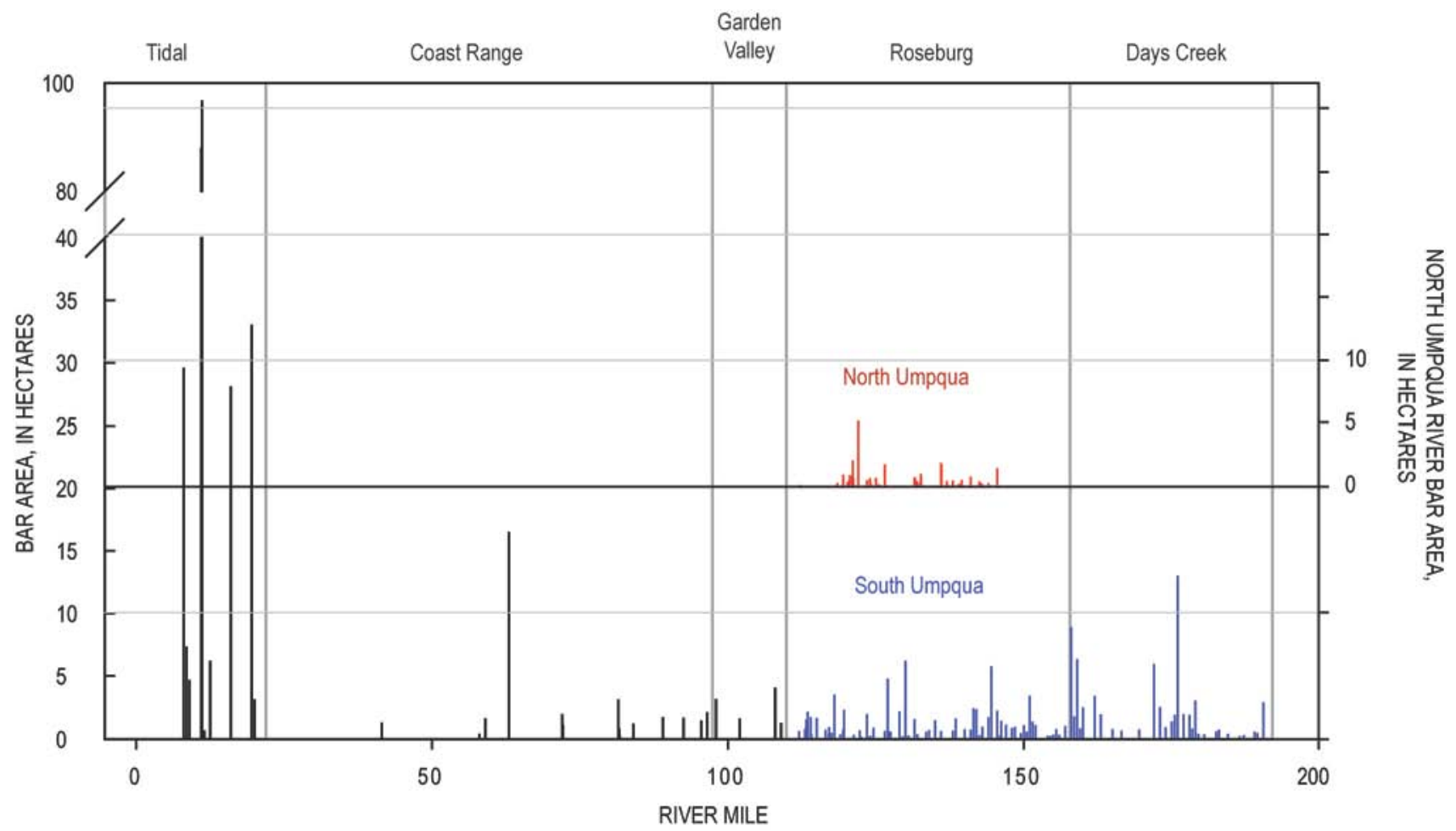

Figure 9. Distribution and size of fluvial sediment accumulations in the Umpqua River, southwestern Oregon, study area as mapped from 2005 National Agriculture Imagery Program aerial photographs at a scale of $\sim 1: 5,000$. Within the Tidal Reach (RM 0-27.5), mapped areas consists primarily of extensive vegetated mud flats; elsewhere, mapped areas are primarily gravel bars. For plotting purposes, river miles for the North Umpqua Reach (RM 0-36) have been added to the Umpqua River at the confluence of the North and South Umpqua Rivers (RM 111.8). 
The broad-scale mapping for the entire study area shows that most numerous gravel bar deposits are along the South Umpqua River, especially the Roseburg Valley Reach, where both the frequency and size of gravel bars exceed gravel deposits on the North Umpqua and mainstem Umpqua Rivers (except the Tidal Reach) by at least a factor of two (fig. 10; table 1). From the confluence of the North and South Umpqua Rivers downstream, the frequency of gravel bars diminishes and sand and gravel accumulations are sparse. An exception is Maupin Bar at RM 63, with an area of 38 acres $\left(153,000 \mathrm{~m}^{2}\right)$, which stands out at about 10 times larger than other bars along the Coast Range Reach of the Umpqua River. Although the Tidal Reach has several very large sediment accumulations within and flanking the channel, these features are chiefly mud and sand flats and are not directly comparable with the gravel bars upstream. Findings from the bar mapping are corroborated by our field observations, which revealed only rare gravel deposits along the mainstem Umpqua River, even at the heads of rapids and insides of meander bends where gravel deposits typically accumulate in rivers of this size and gradient.

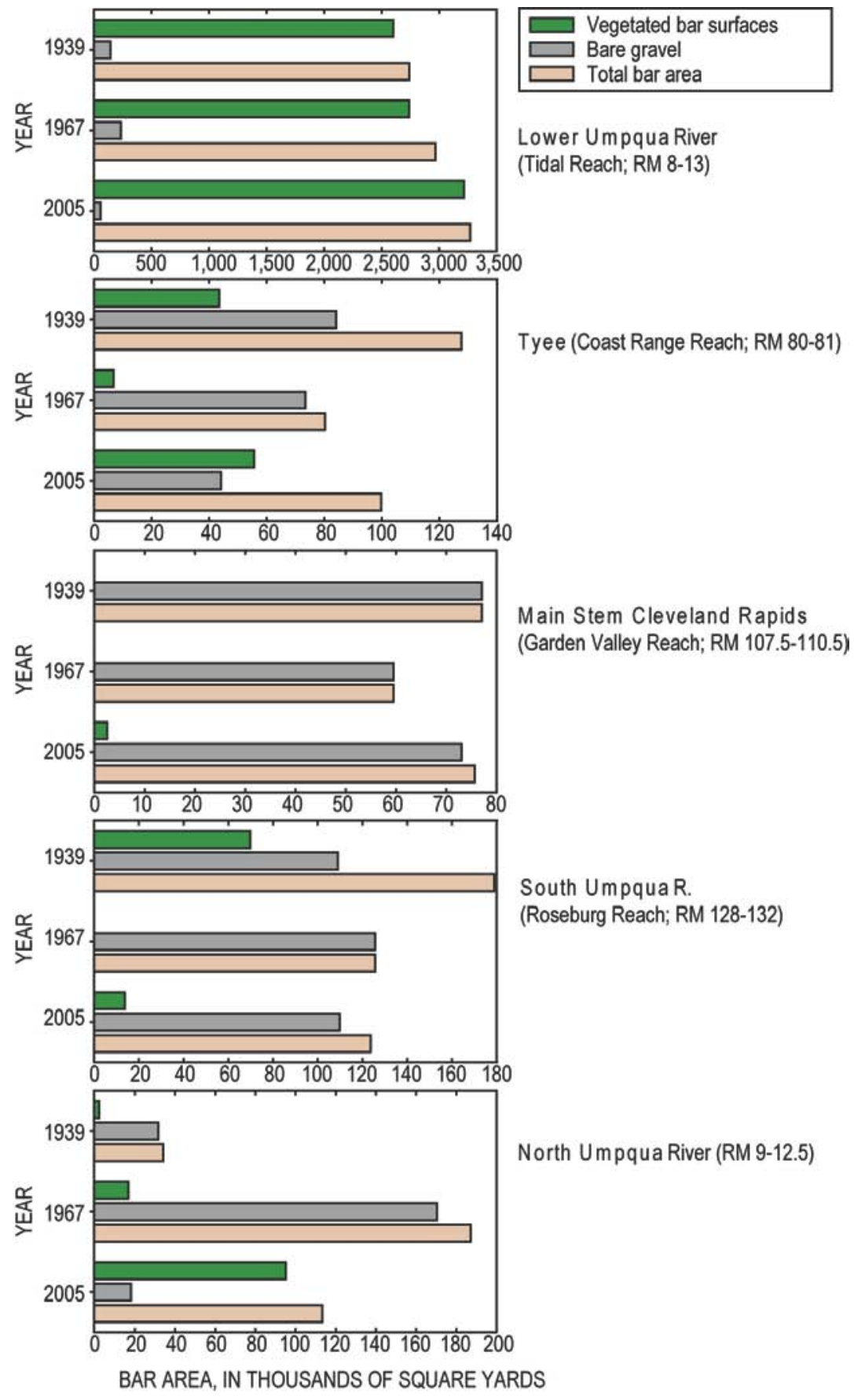

Figure 10. Mapped bar areas for selected reaches of the Umpqua River basin, southwestern Oregon, from aerial photographs dated 1939, 1967, and 2005. 
The systematic decline in the frequency and size of gravel bars from the South Umpqua River through the Garden Valley and Coast Range Reaches must owe to (1) downstream reduction of bedmaterial fluxes (due either to particle abrasion or inchannel storage) or (2) recent acceleration of bedmaterial supply to the South Umpqua River that has not yet made it downstream.

To determine whether there were obvious temporal trends that might partly explain the distribution of gravel bars, we selected five sites for detailed mapping from repeat sets of aerial photographs: the lower Umpqua River (RM 8-13; Tidal Reach), Tyee (RM 80-81; Coast Range Reach), Cleveland Rapids (RM 107.5-110.5; Garden Valley Reach), South Umpqua River (RM 128-132; Roseburg Reach) and North Umpqua River (RM 9-12.5). For each site, we scanned and rectified aerial photographs from 1939 and 1967 to supplement the existing 2005 NAIP orthophotographs. Digitization for the detailed mapping was conducted at 1:3,000 for all sites except for the much larger lower Umpqua reach, which was digitized at a scale of 1:10,000. The detailed mapping entailed digitizing the wetted channel, gravel bars and active channel boundary. Gravel bars were further subdivided into vegetated and unvegetated areas, where unvegetated was considered to be areas with less than 20 percent vegetative cover. Although ancillary datasets, such as the 1:24,000 USGS topographic maps and the 1995 and 2000 USGS orthophotographs, were used to aid in the identification of gravel bars, these results should be considered preliminary, because it is difficult in some instances to distinguish bedrock shoals capped by a thin veneer of gravel from thicker "bar-like" deposits of gravel.

The historical channel mapping shows no systematic trends in bar area or channel for 1939-2005 (figs. 10-15). Several locations had decreased bar area between 1939 and1967, which likely was due to erosion by the 1964 flood. At the Tyee site (fig. 11), a large midchannel bar feature eroded between 1939 and 1967, followed by bar growth between 1967 and 2005. Similarly, the bar at RM 109 in the Cleveland Rapids photograph site (fig. 12) was present in the 1939 photographs, was absent in 1967 and then reappeared with larger area by 2005. The largest changes in channel morphology were near RM 130 on the South Umpqua River, where the channel avulsed around a large midchannel island between 1939 and 1967 (fig. 13). Gravel bars at the North Umpqua River photograph site (fig. 14) increased in area and frequency 1939-67, but many of these newly deposited surfaces appeared vegetated, inactive or were eroded by 2005, resulting in a decrease in bar area. At nearly all bars mapped between 1939 and 2005, losses in bar area 1939-67 are coupled with decreases in the vegetated bar area, and aerial photographs show that many of the vegetated bars present in the 1939 photographs were bare gravel in the 1967 photographs, probably owing to the high flows of 1964. 

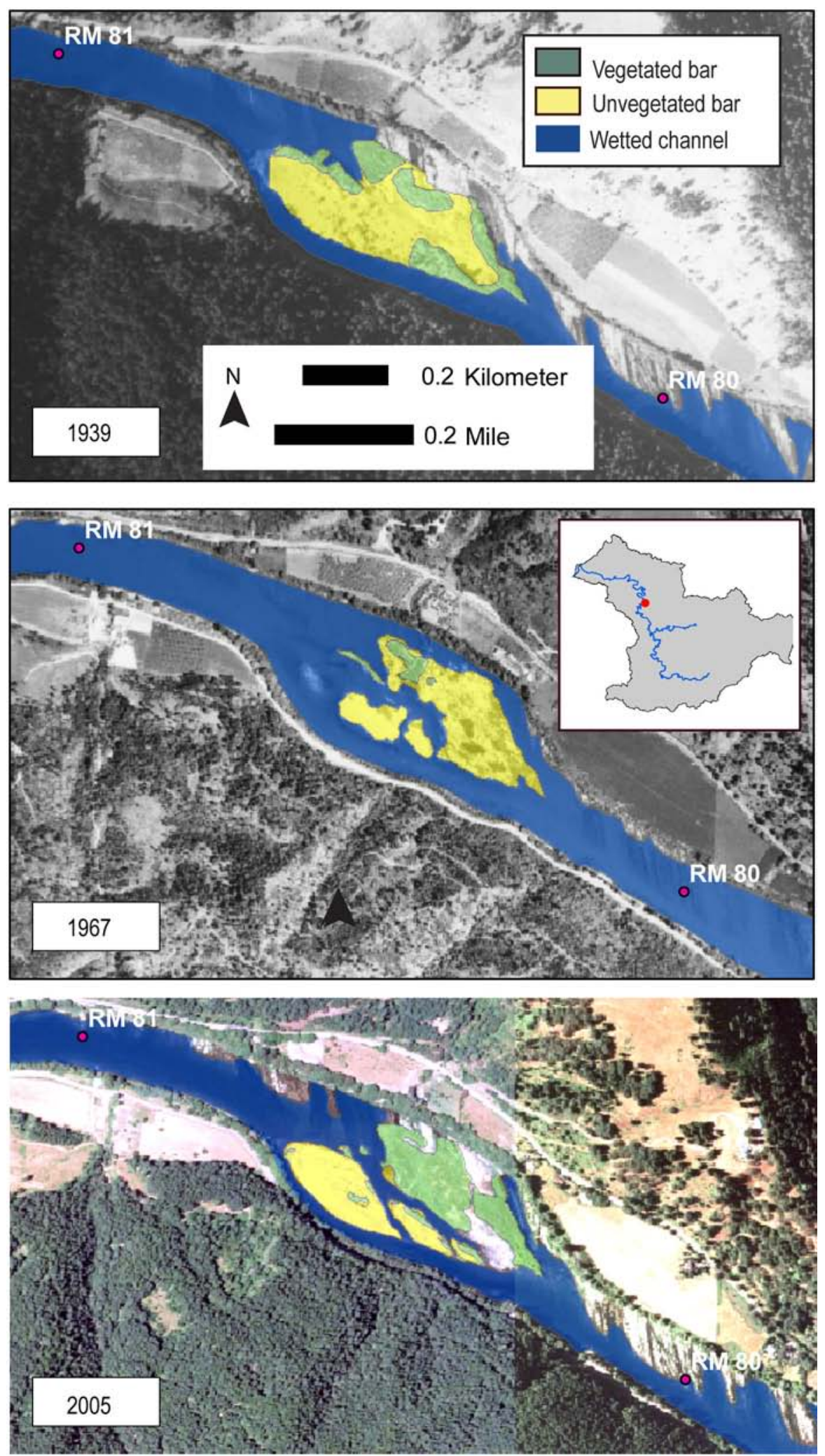

Figure 11. Mapped channel and bar features for the Umpqua River at Tyee site, southwestern Oregon, 1939-2005. 

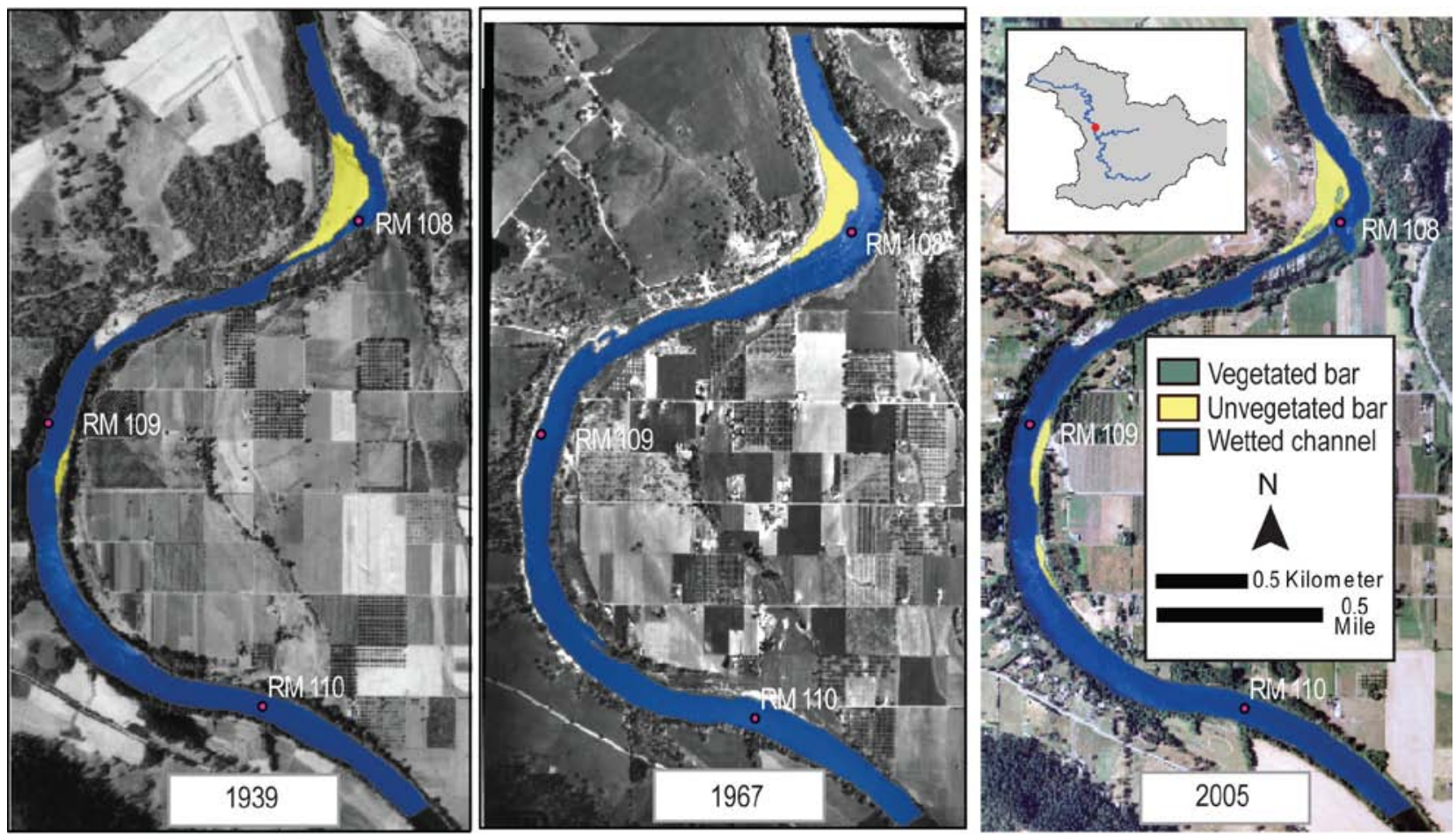

Figure 12. Mapped channel and bar features for the Umpqua River at Cleveland Rapids site (RM 107.5-110.5), southwestern Oregon, 1939-2005.
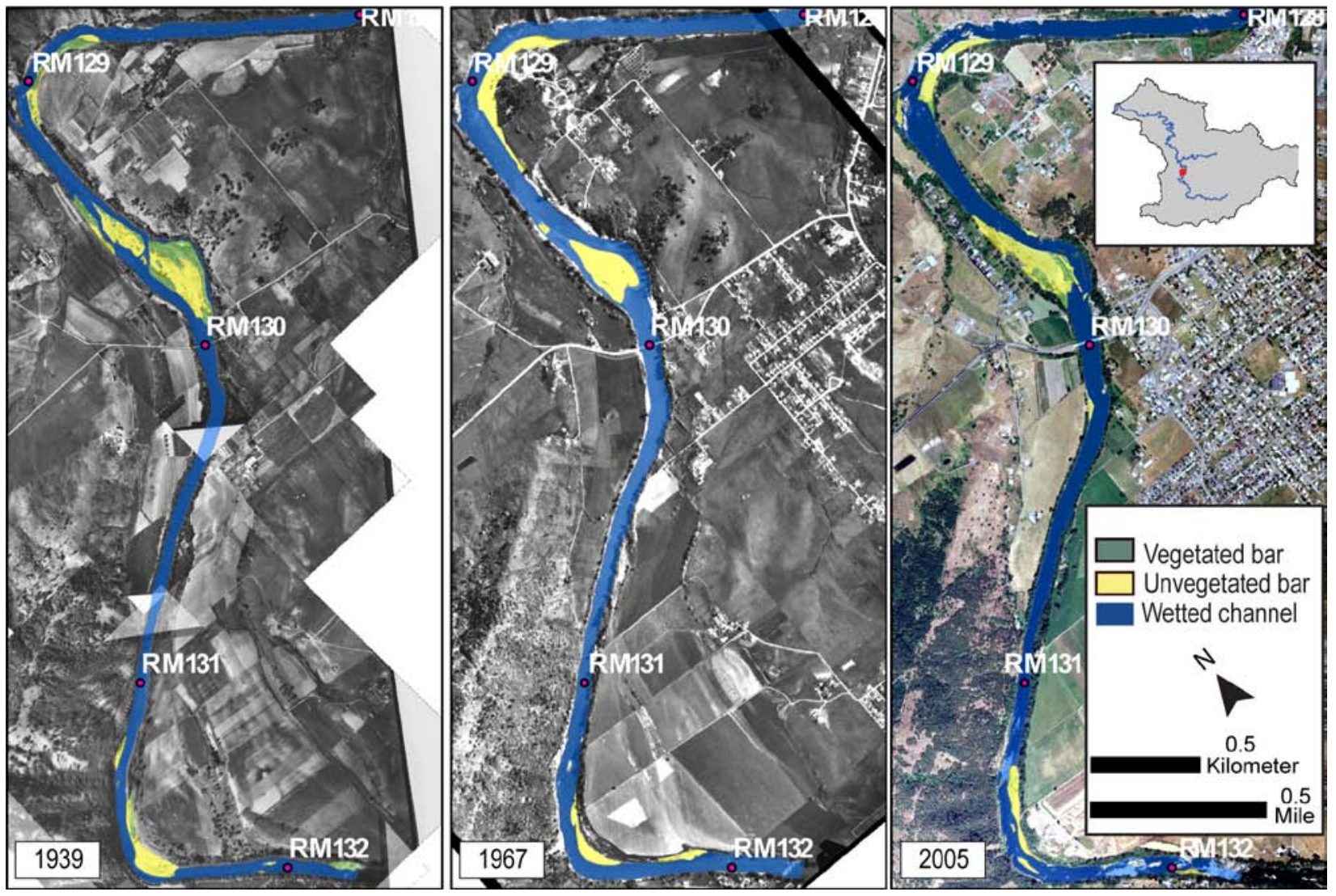

Figure 13. Mapped channel and bar features at the South Umpqua River site (RM 128-132), southwestern Oregon, 1939-2005. 

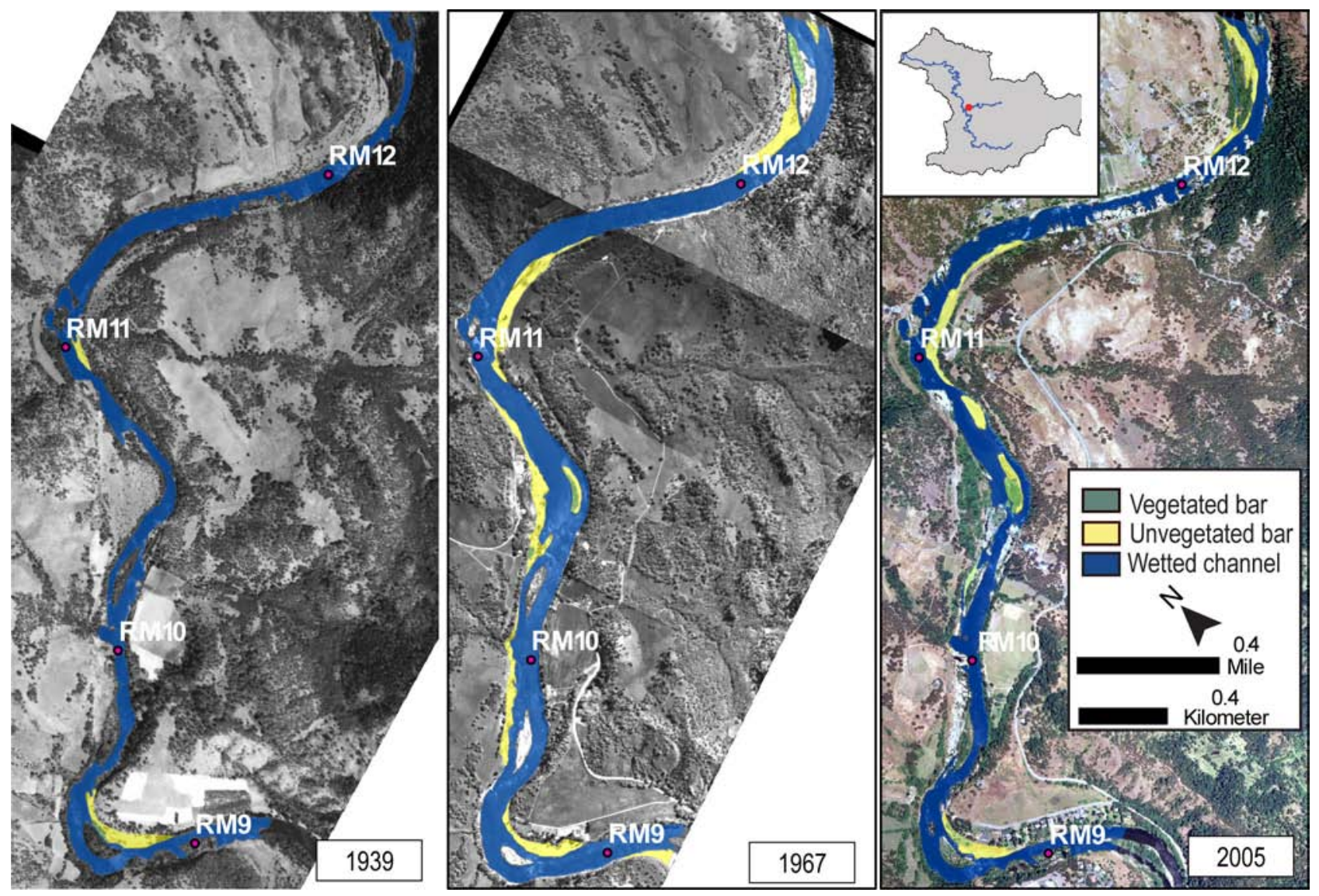

Figure 14. Mapped channel and bar features at the North Umpqua River site (RM 9-12.5), southwestern Oregon, 1939-2005.

The lower Umpqua River photograph site (fig. 15) was the only location that displayed systematic increases in the area of bars and island. However, the bars and islands mapped in this tidal reach are likely composed of sands and fine sediments, and are not active gravel bar surfaces like those observed along the fluvial reaches. The large islands in this reach remained fairly stable in terms of their overall shape, but did grow in size, especially near RM 9-11 downstream of the Smith River confluence.

From this preliminary analysis, the primary conclusion is that these bars are dynamic features acting as a source and sink for bed material in a manner apparently related to recent flow history. More systematic mapping for longer reaches and more time intervals would be required for documenting longer term temporal and longitudinal trends. Such mapping would also be a basis for morphologybased transport rates similar to those conducted on other Western rivers (see, for example, Ham and Church, 2000). 

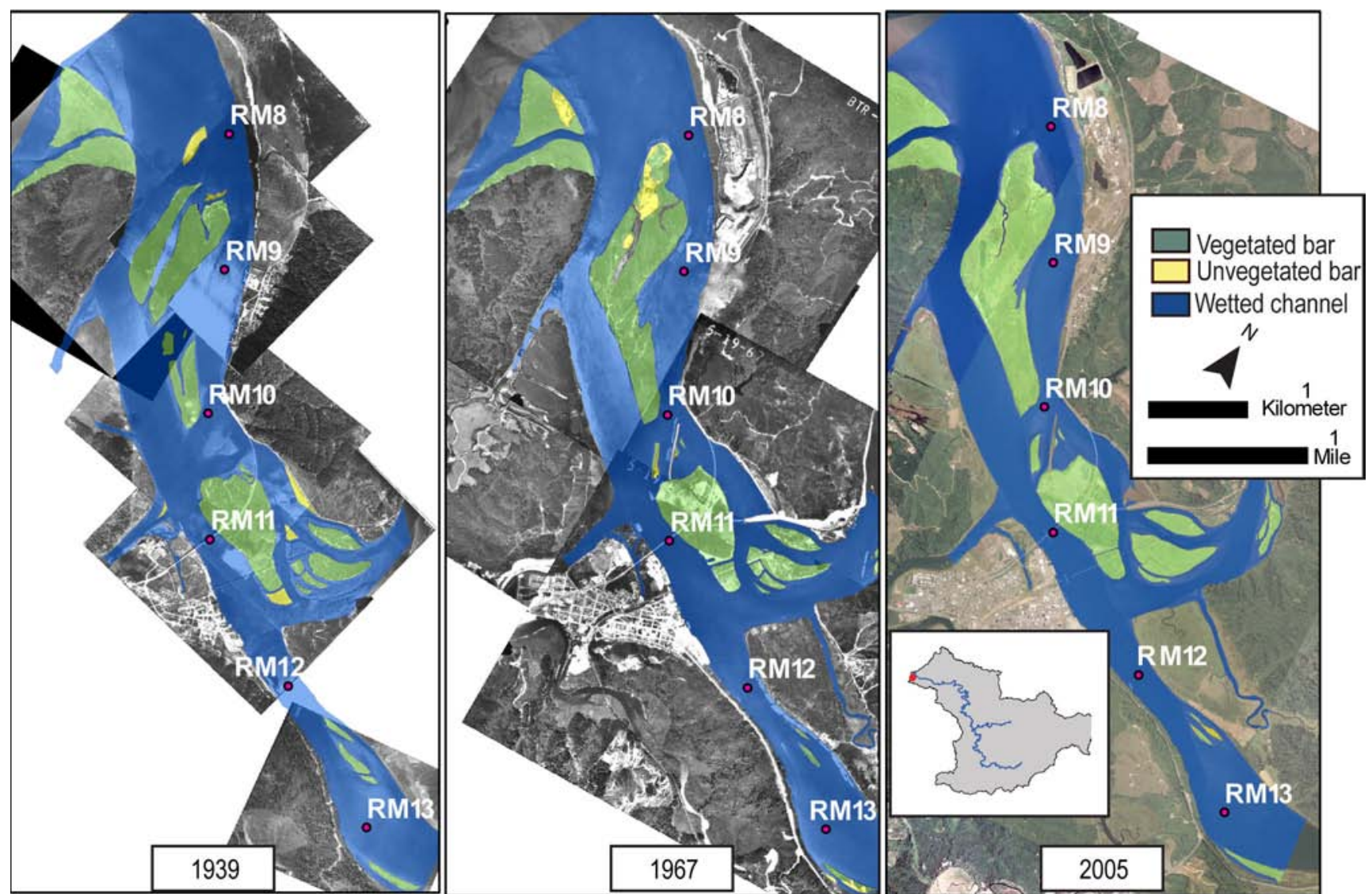

Figure 15. Mapped channel and bar features at the Lower Umpqua River site (RM 8-13), southwestern Oregon, 1939-2005.

\section{Gravel Bar Particle Size Analyses}

During the November 2008 site visit, we measured surface particle-size distributions at five gravel bars in the study area: Umpqua River near Cougar Creek (RM 93; Coast Range Reach), Umpqua River near Cleveland Rapids Bar (RM 109; Garden Valley Reach), South Umpqua River at Umpqua Sand and Gravel Bar (RM 115.2; Roseburg Reach), South Umpqua River at Days Creek Bar (RM 172; Days Creek Reach), and two surface measurements at North Umpqua River near Singing Waters Road (RM 9.2 and RM 9.5). Measurements of particles on the bar surface were determined using Wolman (1952) pebble count methodology and gravelometer (a measurement template), which allows for the rapid, standardized measurement of clasts greater than $2 \mathrm{~mm}$ in diameter. To determine particle size for the subsurface layer of gravel bars, we took bulk samples from the bar apex at four of the six sites where surface measurements were conducted. These bulk samples were analyzed for size distribution by the USGS sediment laboratory in Vancouver, Washington.

Plots of particle-size data (fig. 16) indicate that the bar subsurface is finer than the surface layer. A coarse surface layer (or armoring) is typically observed on gravel-bed rivers, and can result from the selective scouring of fines or selective deposition of large particles (Bunte and Abt, 2001). The degree of armoring is indicated by the ratio of the $\mathrm{D}_{50}$ (median grain size) of the surface layer to the $\mathrm{D}_{50}$ of subsurface layer. For rivers with a high sediment supply, this ratio is typically close to 1 , whereas for rivers where the transport capacity exceeds sediment supply, bar surfaces become armored and will have armoring ratios approaching 3 in the extreme case of energetic rivers with little or no sediment supply (Bunte and Abt, 2001). Armoring ratios determined for the Umpqua River show that transport 
capacity may significantly exceed sediment supply at the North Umpqua River and Cleveland Bar (mainstem Umpqua River) sites where $\mathrm{D}_{50}$ surface $/ \mathrm{D}_{50}$ subsurface is approximately 1.9 and 1.83 , respectively. By contrast, the two sites on the South Umpqua River-Umpqua Sand and Gravel location and the Days Creek site-both have lower armoring ratios of 1.13 and 1.25, respectively, potentially indicating that sediment supply more closely approximates with transport capacity. These results are consistent with the greater area and abundance of gravel bars on the South Umpqua River, although the widespread presence of channel bedrock indicates that transport capacity at least marginally exceeds supply for the South Umpqua River. For all reaches, subsequent such analyses will require careful sampling to avoid areas of recent gravel mining or recreational disturbance, so that the measured armoring ratios reflect actual transport and sediment supply conditions.

Comparison of particle-size data from all sites (fig. 16) show that coarsest surface layers were measured at the two Umpqua River sites (Cleveland Bar and Cougar Creek Bar) and the South Umpqua River at Days Creek Bar. The two North Umpqua River sites were located at the upstream and downstream ends of a long $(0.3 \mathrm{mi})$ bar that extended alongside a bedrock rapid. Although the bar surface at the downstream site is coarser than the upstream site, this probably is due to its position at the base of the rapid, whereas the finer upstream site was located near a pool, upstream of the rapid, indicating the important role of local site conditions on depositional patterns and bed-material size.

Because particle size was measured at only six sites, which span more than 90 river miles and three rivers, it is difficult to determine longitudinal trends such as downstream fining. Although additional data are needed to draw more conclusive findings, it does appear that grain size decreases along the length of the South Umpqua River from the Days Creek site (RM 172) to the Umpqua River Sand and Gravel site (RM 115). Measurements from the two mainstem Umpqua River sites suggests that gravel bars may coarsen downstream of the confluence with the North and South Umpqua Rivers, perhaps indicating local sediment sources, but additional data are needed to confirm this trend. Additional particle-size measurements, as well as assessment of rock types composing the gravel bars, could significantly aid in determining key aspects of the sediment budget by providing quantitative measures of sediment source areas, downstream fining, and downstream changes in transport capacity relative to sediment supply. 
A
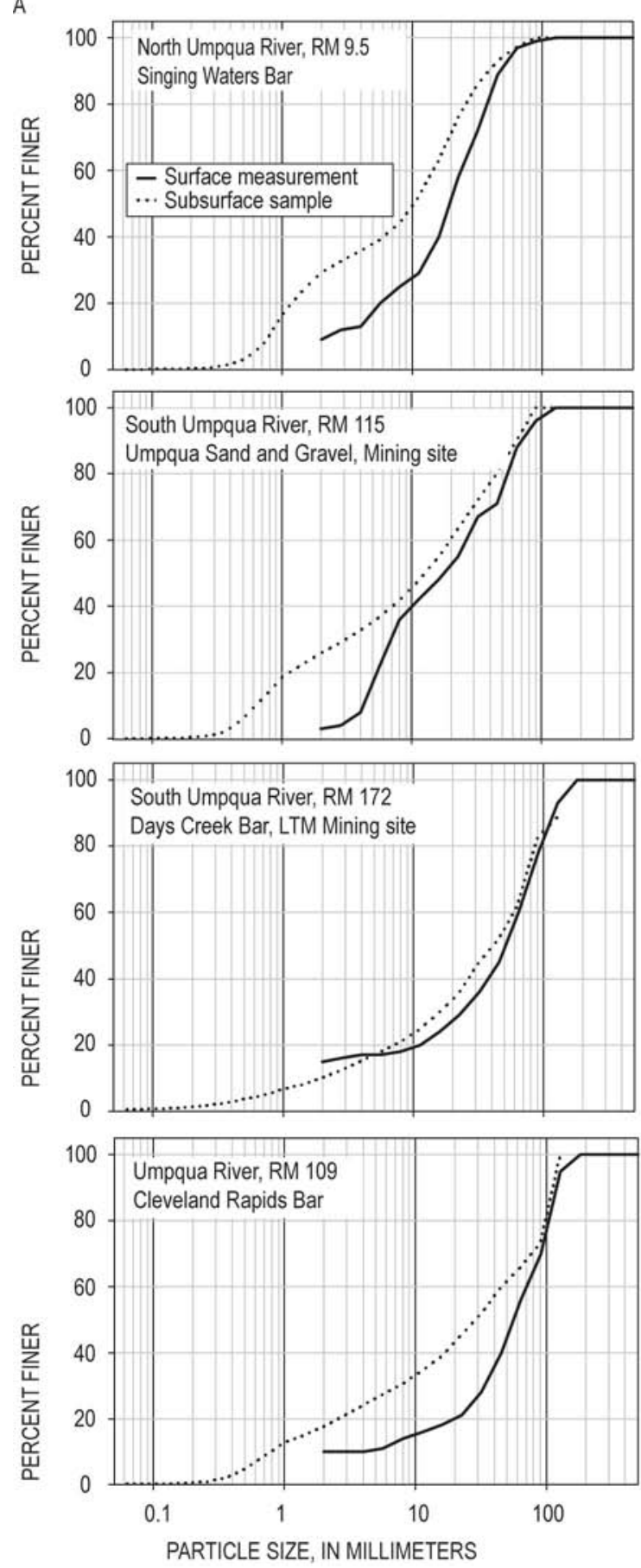

B

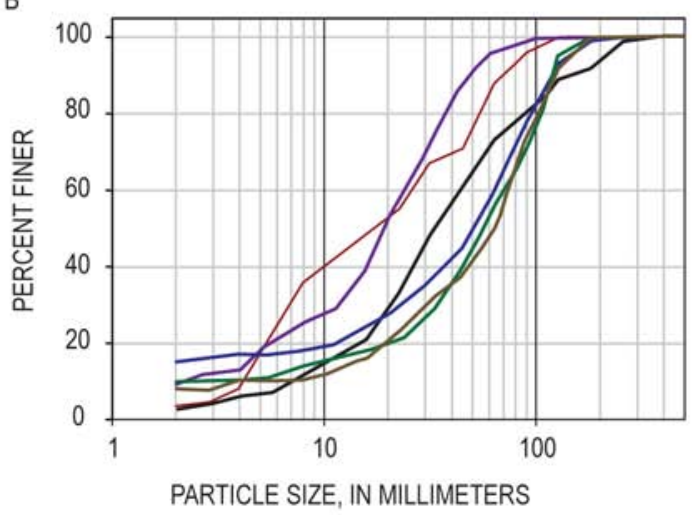

N. Umpqua R., Singing Waters Bar downstream end, RM 9.2

N. Umpqua R., Singing Waters Bar upstream end, RM 9.5

Umpqua R., Cougar Creek Bar, RM 93

Umpqua R., Cleveland Rapids Bar, RM 109

S. Umpqua R., Umpqua Sand and Gravel mining site, RM 115

S. Umpqua R., Days Creek Bar, LTM Mining site, RM 172

Figure 16. Particle-size distribution for gravel bars In the North Umpqua River basin, southwestern Oregon, sampled during a November 2008 field reconnaissance. A. Subsurface and surface comparisons for four sampled bars. Surface size distribution measured by Wolman (1952) count of 100 clasts; subsurface distribution from bulk sample below armor layer of approximately 100 pounds. B. Comparison of bar surface grain size distributions for six bars. N., North; S., South; R. River. 


\section{Summary of Findings}

On the basis of field observations and datasets reviewed in this study, the Umpqua River above river mile (RM) 27.5 flows mostly on bedrock, indicating that the river is in a long-term (over timescales of thousands of years) state of incision. This is most likely a response to ongoing uplift of the Coast Range and adjacent terrains in response to regional geologic forces. Furthermore, many reaches of the Umpqua River system have relatively few gravel bars, and historical documents indicate that these same reaches were gravel-poor in the 19th and early 20th centuries. The extensive presence of inchannel bedrock, combined with a paucity of gravel bars, indicates that the Umpqua River upstream of the Tidal Reach was historically, and still is, sediment supply limited-meaning that transport capacity exceeds the volume of sediment entering the river system. Nevertheless, the South Umpqua River contains distinctly more abundant gravel bars, and operator surveys indicate that these gravel bars are dynamic features - replenished and locally eroded by high flows.

Although there are more gravel bars in the South Umpqua River, especially downstream of the Cow Creek confluence, it is unclear what happens to this gravel once it enters the mainstem Umpqua River downstream of the confluence of the forks. Specific gage analyses, temporal changes in bar area, and other information reviewed in this study do not reveal clear trends in channel condition away from historic conditions (such as aggradation or enhanced incision rates), but this preliminary conclusion requires more analysis because the extensive inchannel bedrock limits the incision potential, and channel response is more likely manifested by more subtle changes in channel and bar morphology. The Tidal Reach is the only one for which available data indicates persistent channel incision and where cross-sections and previous reports indicate that sand and gravel extraction has exceeded sediment supply. Bed material supply in the Umpqua River system has likely been influenced by many anthropogenic factors, including dams, placer mining, forest practices, and instream gravel mining, but the relative effects of each of these factors have not yet been determined.

\section{Outstanding Issues and Possible Approaches}

\section{Bed-Material Budget}

A bed-material budget would provide critical information for understanding possible effects of instream gravel mining. Because the existing instream gravel mining operations are located along the South Umpqua River, a logical first step would be to develop a bed-material budget for those reaches most affected by instream mining: the Days Creek, Roseburg, and Garden Valley Reaches. An expedient and relevant approach for developing this sediment budget could entail the following strategy:

1. Employ a GIS-based approach to develop correlations between physiography, geology, and other established predictor variables and sediment production. Similar approaches have been applied to the Deschutes River (O’Connor and others, 2003), and the North Umpqua River (Stillwater Sciences, 2000), but here the GIS-based estimates could be calibrated against extensive sediment data collected by the USGS during 1950-70 and available (and possibly newly acquired) reservoir surveys.

2. Apply a modified version of the morphological approach, which typically involves estimating sediment flux based on mapped changes in bar area between two time periods. Because gravel deposits along the Umpqua River system are difficult to discern accurately from aerial photographs, a modified approach, involving field mapping in conjunction with existing and ongoing operator surveys of erosion and deposition, would be required to obtain interpretable results. Although a morphologically based approach would be subject to large uncertainties, it could be used to judge the reasonableness of the GIS analysis and allow an independent assessment of possible temporal 
trends. Such data also could provide baseline information from which to design efficient monitoring strategies.

3. Analyze lithology (rock type) of gravel deposits to provide information on the relative contribution of bed-material from different source areas, as well as information on downstream clast disintegration.

4. Although direct measurements of bedload transport can be used to verify equations for bedload transport and to estimate actual bedload fluxes, such an approach is unlikely to provide useful information on a supply limited system such as the Umpqua River unless such measurements were conducted for several years over a large range of flow conditions.

\section{Legacy and Ongoing Effects of Placer Mining, Forest Practices, Impoundments and Instream Gravel Mining}

A key question, particularly for the South Umpqua River, is how past activities, such as late 19th century placer mining, 20th century forest practices, instream gravel mining, and the Galesville Reservoir impoundment, have affected the present day gravel flux rates. Similarly, impoundments and forest practices may have had discernible effects on bed-material transport in the North Umpqua River. These questions are challenging because of the various time lags-perhaps up to centuries-involved in channel response, and the interactions of changed transport rates with various channel and floodplain areas that serve as storage and source areas for bed material. Although it may be difficult to quantify the exact effect of gravel extraction, placer mining or dam building on specific aspects of the gravel budget, examination of changes in channel morphology along potentially affected reaches may reveal trends attributable to certain activities. We anticipate that the most useful approach to deduce the relative importance of past activities is to employ a combination of:

1. Mapping the distribution of areas of active gravel transport and to analyze temporal trends in channel and floodplain morphology in light of known areas of land-use disturbance: To assess the possible effects of placer mining, such analyses would include the affected and downstream reaches of Cow Creek, Myrtle Creek, and Lookingglass Creek.

2. Resurveying cross-sections originally surveyed in the 1970s for a USGS flood study: By reoccupying cross-sections in reaches potentially affected by impoundments or placer mining, temporal trends attributable to these activities may be determined.

\section{Connections between Upstream Umpqua River and Tributaries and the Tidal Reach}

Channel characteristics in the Tidal Reach are a function of upstream sediment supply as well as geologic conditions over the past 10,000 years. The sparse extent and volume of gravel bars (historically and presently) in the Coast Range Reach hints that bed-material fluxes have been small over the last few centuries, indicating that gravel from upstream is stored in the Garden Valley Reach or is disintegrating downstream. If either of these scenarios is valid, then much of the sediment in the Tidal Reach may reflect previous geologic conditions or inputs (for example, enhanced sediment production during the millennia after the Mazama eruption could have resulted in extensive aggradation in the Tidal Reach). Alternatively, much of the sediment supplying the Tidal Reach may derive from tributaries directly entering the Tidal or lower Coast Range Reaches. Understanding the relative roles of current, historic, and prehistoric sediment dynamics is necessary to predict the response to the estuary to upstream perturbations. To address these issues, we would: 
1. Extend the GIS analyses, gravel lithology assessments, and morphologic budget approach to the Coast Range and Tidal Reaches so as to better understand sediment production and temporal changes in sediment flux for the entire Umpqua River study area.

2. Resurvey the bathymetry of the Tidal Reach in order to better understand spatial and temporal patterns of sediment replenishment in formerly mined areas. Although past surveys are available for various sections of the Tidal Reach, a new survey could judiciously target areas that have not been mined for various time periods (for example, 2, 5, 10, and 20+ years), in order to determine how these sites have recovered following gravel extraction.

3. Reoccupy cross-sections surveyed for a 1970s USGS flood study. To better understand how the Tidal Reach responds to sediment supply conditions in the upper reaches of the Umpqua River, a series of key cross-sections in the Coast Range and Garden Valley Reaches could be reoccupied and examined to determine decadal scale changes in channel condition.

\section{Balance between Sediment Supply and Transport Capacity}

The long-term (decades to centuries) evolution of the Umpqua River will depend on the balance between sediment supply and transport capacity. Both factors likely have and will continue to be affected by dam building, flow regulation, and channel manipulation. An analysis of relative transport capacity could include:

1. Assessment of gravel bar armoring ratios as described above. Although local site conditions exert strong influence on grain size characteristics, multiple measurements of surface and subsurface clast sizes may indicate longitudinal trends in relative transport capacity. Such observations may also support inferences of temporal changes in bed-material conditions drawn from other study components.

2. Hydraulic modeling of selected reaches will enable estimation of transport capacity and its relation to sediment supply for a variety of future scenarios. One approach could be to develop a simple 1D (HEC-RAS) model for the Days Creek, Roseburg, and Garden Valley Reaches, allowing us to estimate sediment transport capacity for a range of flows. The longitudinal variation in transport capacity can then be compared against estimates of sediment supply and observed location of erosion and deposition as well as gravel-bar armoring ratios. The purpose of the model is not to directly estimate sediment transport using equations of bedload transport; as such an approach is not suited to the Umpqua River basin because these equations assume unlimited sediment supply, but rather to provide a basis for evaluating the balance between supply and potential transport for various flow and sediment supply scenarios. 


\section{References Cited}

Beckham, S.D., 1986, Land of the Umpqua, a history of Douglas County, Oregon: Roseburg, Oregon, Douglas County Commissioners, 285 p.

Bunte, K., and Abt, S.R., 2001, Sampling surface and subsurface particle-size distributions in wadeable gravel- and cobble-bed streams for analyses in sediment transport, hydraulics, and streambed monitoring: Fort Collins, Colorado, USDA Forest Service, Rocky Mountain Research Station, General Technical Report RMRS-GTR-74, 428 p.

CH2M-Hill, 1971, Umpqua River gravel study for Umpqua River navigation company: Corvallis, Oregon, 29 p.

Curtiss, D.A., 1975, Sediment yields of streams in the Umpqua River Basin, Oregon: U.S. Geological Survey Open-File Report, 1 plate with text.

Dana, J.D., 1849, Geology, United States exploring expedition during the years 1828, 1839, 1840, 1841, 1842, under the command of Charles Wilkes, U.S.N. [Volume X]: New York, Putnam, 756 p.

Diller, J.S., 1914, Mineral resources of southwestern Oregon: U.S. Geological Survey Bulletin 546, 147 p.

Douglas, D., 1914, Journal kept by David Douglas during his travels in North America 1823-1827, together with a particular description of thirty-three species of American oaks and eighteen species of Pinus, with appendices containing a list of the plants introduced by Douglas and an account of his death in 1834: Published under the direction of the Royal Horticultural Society: London, William Wesley \& Son, 349 p.

Ham, D.G., and Church, M., 2000, Bed-material transport estimated from channel morphodynamics: Chilliwack River, British Columbia: Earth Surface Processes and Landforms, v. 25, p. 1123-1142.

Harris, D.D., Hubbard, L.L., and Hubbard, L.E., 1979, Magnitude and frequency of floods in western Oregon: U.S. Geological Survey Open-File Report 79-553, 29 p.

Jones, B.E., and Stearns, H.T., 1930, Water-power resources of the Umpqua River and its tributaries, Oregon: U.S. Geological Survey Water-Supply Paper 636-F, p. 221-330.

Klingeman, P.C., 1973, Indications of streambed degradation in the Willamette Valley: Corvallis, Oregon: Water Resources Research Institute, WRRI-21, 99 p.

Moser, S.A., 1976, Umpqua River navigability study: Salem, Oregon Division of State Lands, 131 p.

O’Connor, J.E., Grant, G.E., and Haluska, T.L., 2003, Overview of geology, hydrology, geomorphology, and sediment budget of the Deschutes River basin, Oregon, in O’Connor, J.E., and Grant, G.E., eds., A peculiar river-Geology, geomorphology, and hydrology of the Deschutes River, Oregon: American Geophysical Union Water Science and Application Series No. 7, p. 7-29.

Onions, C.A.,1969, Sediment transport in streams in the Umpqua River basin, Oregon: U.S. Geological Survey Open-File Report, 45 p.

Oster, E.A., 1972, Flood profiles in the Umpqua River basin, Oregon, Part 1: U.S. Geological Survey Open-File Report, 119 p.

Oster, E.A., 1973, Flood profiles in the Umpqua River basin, Oregon, Part 2: U.S. Geological Survey Open-File Report, 113 p.

Oster, E.A., 1975, Flood profiles in the Umpqua River basin, Oregon, Part 3: U.S. Geological Survey Open-File Report, 108 p.

Ramp, L., 1972, Geology and mineral resources of Douglas County, Oregon: Oregon Department of Geology and Mineral Industries Bulletin 75, 105 p.

Scott, L.M., 1923, John Work's journey from Fort Vancouver to Umpqua River, and return, in 1834: Oregon Historical Quarterly, v. 24, p. 238-268. 
Stillwater Sciences, 2000, North Umpqua cooperative watershed analysis, Technical appendix to the synthesis report, Appendix 2-1, Sediment budget for the North Umpqua River basin, Prepared for Pacificorp, North Umpqua hydroelectric project, FERC Project No. 1927: Portland, Oregon, 113 p.

U.S. House of Representatives, 1871, On navigation of Umpqua River: House Miscellaneous Document, $41^{\text {st }}$ Congress, $3^{\text {rd }}$ session, No. 21.

U.S. House of Representatives, 1911, Examination of Umpqua River, Oregon: House Miscellaneous Document, $62^{\text {nd }}$ Congress, $2^{\text {nd }}$ session, No. 276.

Winterbotham, J., 1994, Umpqua-The lost county of Oregon: privately published, 156 p. [Available at http://truefresco.org/bookshop/4_14279241_B0006P7PLQ_Umpqua-The-lost-county-of-Oregon.html, accessed March 10, 2009]

Winterbothom, J., 2000, Footsteps on the Umpqua: Lebanon, Oregon, Dalton Press, 252 p.

Wolman, M.G., 1954, A method for sampling coarse river-bed material: American Geophysical Union Transactions, v. 35, p. 951-956. 